PRZEGLĄD NAUK HISTORYCZNYCH 2017, R. XVI, NR 1

http://dx.doi.org/10.18778/1644-857X.16.01.10

Matgorzata Karkocha

UNIWERSYTET ŁÓDZKI

\title{
Wystrój i wyposażenie kościoła parafialnego w Małogoszczu w świetle inwentarza z 1856 roku
}

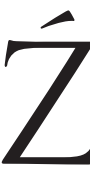

ródła do dziejów kościoła i probostwa parafii katolickiej w Małogoszczu były już przedmiotem edycji na łamach „Przegladu Nauk Historycznych", jak również innych periodyków. Ukazały się artykuły omawiające uposażenie parafii małogoskiej w 1792 r. ${ }^{1}$ oraz protokół wizytacji dziekańskiej z 1830 r. ${ }^{2}$ Prezentowany poniżej opis stanu świątyni parafialnej jest częścią składowa inwentarza fundi instructi, sporzadzonego w dniu 5 (17) lipca 1856 r. po śmierci miejscowego plebana, ks. Tomasza Świątkowskiego ${ }^{3}$. Na źródło to natrafiono w czasie kwerendy przeprowadzonej w Archiwum Diecezjalnym w Kielcach, w księdze zatytułowanej Małogoszcz. Dokumenty różne z XIX wieku (luzem, nieuporządkowane), oznaczonej sygnaturą IIPM-I/6. Inwentarz został spisany w języku polskim

* Wydział Filozoficzno-Historyczny, Instytut Historii, Katedra Historii Nowożytnej, e-mail: malkarkocha@o2.pl.

${ }^{1}$ Por. M. Karkocha, Uposażenie parafii Małogoszcz $w$ świetle sumariusza z 1792 r., „Przegląd Nauk Historycznych” 2016, R. XV, nr 1, s. 249-276.

${ }^{2}$ Ead e m, Opis wizyty dziekańskiej kościoła parafialnego w Małogoszczu z roku 1830, „Przegląd Nauk Historycznych” 2016, R. XV, nr 2, s. 261-283.

${ }^{3}$ Tomasz Świątkowski (1786-1855) - doktor teologii, kanonik i oficjał kielecki, proboszcz małogoski od 1836 r. aż do śmierci 28 VIII 1855 r. Pochowano go na cmentarzu grzebalnym w Małogoszczu na wzgórzu Babinek. Por. Archiwum Diecezjalne w Kielcach [dalej: ADK], Akta konsystorskie ogólne. Życiorysy kapłanów 1835, sygn. OP-X/4b, k. 206-206v; ibidem, Akta konsystorskie. Status cleri 1847-1929, sygn. OP-X/13, k. 1012-1013; oraz J. W iś n i e w s ki, Historyczny opis kościołów, miast, zabytków i pamiątek w Jędrzejowskiem, Marjówka 1930, reprint Kielce 2000, s. 138, 272-273 (na s. 138 błędna informacja, jakoby Świątkowski zmarł w 1856 r., a na s. 272, że urodził się 1785 r.). 
na kartkach formatu zbliżonego do A4, zapisanych obustronnie, ponumerowanych od 1 do 77 , oznaczonych współcześnie jako k. 41-794. Pismo jest czytelne, staranne, a w tekście dokonano nielicznych poprawek. Spis przeprowadziła specjalna komisja złożona $z$ osób duchownych (dziekana kieleckiego ks. Stanisława Zygmuntowicza ${ }^{5}$ i nowo obranego proboszcza, ks. Nestora Bierońskiego ${ }^{6}$ ) oraz świeckich (burmistrza miasta Małogoszcz Karola Syktowskiego, prezesa dozoru kościelnego Jana Mieszkowskiego ${ }^{7}$, dwóch jego członków: Jana Saskiego ${ }^{8}$ i Józefa Wodzyńskiego ${ }^{9}$, nadto niewymieniona $z$ nazwiska żonę kościelnego). Poświadczył go i uwierzytelnił pieczęcią naczelnik powiatu kieleckiego w dniu 11 (23) lipca 1856 r.

${ }^{4}$ Pełny tytuł tego dokumentu brzmi: Inwentarz fundi instructi kościoła parafialnego beneficjum w mieście Małogoszczu po śmierci X. Tomasza Świątkowskiego proboszcza na osobę W.X. Nestora Bierońskiego, wiceregensa seminarium kieleckiego, nowo ustanowionego proboszcza w Małogoszczu w roku 1856 sporzadzony.

5 Stanisław Zygmuntowicz (1806-1866) - kapłan diecezji kieleckiej, wyświęcony w 1830 r. Początkowo pełnił funkcję wikariusza w Kurzelowie. W latach 18331866 był administratorem, a następnie proboszczem kościoła parafialnego w Złotnikach. W 1841 r. został mianowany poddziekanem, a w roku 1846 dziekanem diecezji kieleckiej. Por. ADK, Akta konsystorskie. Status cleri 1847-1929, sygn. OP-X/13, k. 1284-1285; ibidem, Akta konsystorskie ogólne. Życiorysy kapłanów 1835-1840, sygn. OP-X/3, k. 30.

${ }^{6}$ Nestor Hygin Soter Bieroński (1816-1899) - kapłan diecezji kieleckiej i wieloletni wykładowca Seminarium Duchownego w Kielcach, proboszcz małogoski w latach 1855-1899. Biogram tego kapłana por. M. Karkocha, Parafia Rembieszyce 1438-2012. Studium z dziejów społeczności lokalnej, Łódź 2013, s. 357-359. Por. też ADK, Akta personalne ks. Nestora Bierońskiego 1842-1890, sygn. XB-19; ibidem, Akta konsystorskie. Status cleri 1847-1929, sygn. OP-X/13, k. 50-51; W. Gi i bartows ki, S.p. ks. Nestor Bieroński, „Przegląd Katolicki” 1899, R. XXXVII, nr 18, s. 281-284; ks. S. Stuczeń, Parafia małogoska i jej ostatni proboszcz ś.p. ks. prałat Nestor Bieroński, „Przegląd Katolicki” 1899, R. XXXVII, nr 21, s. 328-330 oraz nr 22, s. 345-346; J. Wiśniew ski, op. cit., s. 273.

7 Jan Mieszkowski - właściciel wsi Cieśle, dzierżawca Leśnicy i Skorkowa. Por. Protokół wyboru Dozoru Kościelnego w Małogoszczu z 1859 r., ADK, Małogoszcz. Dokumenty różne z XIX wieku (luzem, nieuporządkowane), sygn. IIPM-I/6, k. 105.

8 Jan Saski (1810-1868) - kolator miejscowego kościoła, od 1854 r. dzierżawca rozległych dóbr rządowych w powiecie kieleckim, złożonych z 13 wsi i osad (Ruda, Wesoła, Młynki, Zajaczków, Krawczowskie, Laski, Miedzianka, Podpolichno, Charężów, Gałęzice, Fanisławice, Fanisławiczki i Gnieździska), a wcześniej (w latach 1847-1852) właściciel pobliskiej wsi Mieronice. Jego mogiła znajduje się na cmentarzu parafialnym w Małogoszczu. Por. K. Za pałowa, Rodzina Stefana Żerom skiego w Świętokrzyskiem, Kielce 2003, s. 172 i n.; M. Karko cha, Parafia Rembieszyce..., s. 72, 75; oraz Protokół wyboru Dozoru Kościelnego..., k. 105-105v.

9 Józef Wodzyński - posiadacz realności w Małogoszczu. Por. Protokół wyboru Dozoru Kościelnego..., k. 105-105v. 
Parafia pw. Wniebowzięcia Najświętszej Marii Panny w Małogoszczu ma średniowieczna metrykę. Pierwsza wzmianka o tamtejszym kościele pochodzi z $1141 \mathrm{r}$. Budynek ten wraz $z$ grodem został zniszczony przez Tatarów w 1259 r. Po przeniesieniu miasta na nowe miejsce wzniesiono kościół drewniany pw. św. Mikołaja bpa i św. Małgorzaty, dziewicy i męczennicy. W 1342 r. świątynię hojnie uposażył król Kazimierz Wielki, przekazując miejscowemu plebanowi Janowi i jego następcom zachodnią część miasta oraz rozległy kompleks gruntów, „począwszy od kościoła, lasy, bory, gaje ze wszystkimi pszczelnikami, pożytkami idąc na zachód słońca aż do rzeki zwanej Pierzchnica [...]"10, nadto pobliska wieś Popowice. Nadanie uzupełnione zostało cłem królewskim $z$ miast Małogoszcza, Kurzelowa i Chęcin, ściaganym co dziewiąty dzień, a także dwoma świątnikami spośród miejscowych mieszczan, których zadaniem była obsługa kościoła. Od tego czasu beneficjum małogoskie zaliczane było do bardziej dochodowych. A ponieważ było kolacji monarszej, przeważnie otrzymywali je wysocy dygnitarze duchowni lub osoby mile widziane na dworze królewskim ${ }^{11}$.

Drewniany kościół przetrwał do końca XVI stulecia. Nie wiadomo, co się $z$ nim stało. Prawdopodobnie uległ zniszczeniu wskutek starości i został rozebrany. Obecna świątynia powstała w latach 1591-1595 staraniem ks. Jakuba Biedy Chrostkowica (vel Chrostkowicza, Chrostka) (1560-1630), miejscowego mansjonarza, późniejszego proboszcza i dziekana małogoskiego ${ }^{12}$. Konsekrował ja w 1595 r. biskup chełmiński i wieczysty administrator diecezji

10 Cyt. za: J. Wiśniewski, op. cit., s. 171. Pełny polski przekład tego przywileju: ibidem, s. 170-174; znaczne fragmenty: M. Rawita-Witanowski, Dawny powiat chęciński, oprac. D. Kalina, Kielce 2001, s. 105-106. Tekst nadania w oryginale: J. Wiśs niew ski, op. cit., s. 424-429; edycja źródłowa: Zbiór dokumentów małopolskich, wyd. S. Kuraś, I. Sułkowska-Kuraś [dalej: ZDM], cz. 4 (Dokumenty z lat 1211-1400), Wrocław-Warszawa-Kraków 1969, s. 71-76, nr 927.

${ }^{11}$ J. Wiśniewski, op. cit., s. 116-117; E. Kosik, Parafia małogoska, [w:] W kasztelańskim Małogoszczu. Monografia historyczno-gospodarcza Małogoszcza i okolicy, red. E. Kosik, Kielce 1994, s. 60-61; C. Hadamik, D. Kalina, E. Traczyński, Miasto i gmina Małogoszcz, Kielce 2006, s. 118-119; Miasto i gmina Małogoszcz, Kielce 2006 [seria: Dzieje i zabytki małych ojczyzn, red. R. Mirowski]; M. Rawita-Witanowski, op. cit., s. 104, 108.

12 J. Wiśniewski, op. cit., s. 214-231; M. Rawita-Witanowski, op. cit., s. 109-119; E. Kosik, Chrostowice z Małogoszcza, „Nasza Przeszłość” 1973, R. XL, s. 176-181; ide m, M. Paulewi cz, Budowniczy Małogoszcza Jakub Bieda Chrostkowicz, [w:] W kasztelańskim Małogoszczu..., s. 67-70; ks. S. Stuczeń, Parafia małogoska i jej ostatni proboszcz ś.p. ks. prałat ks. Nestor Bieroński, „Przegląd Katolicki” 1899, R. XXXVII, nr 19, s. 296. 
pomezańskiej Piotr Tylicki (1543-1616) ${ }^{13}$. Jest to budowla orientowana, murowana $z$ kamienia wapiennego i cegły, otynkowana, oszkarpowana na narożach. Ma jedną nawę na planie wydłużonego prostokąta, dwuprzęsłową oraz węższe i niższe od niej prezbiterium, także na planie wydłużonego prostokąta, trójprzęsłowe, zamknięte trójbocznie. Przy prezbiterium od strony północnej mieści się zakrystia i niewielki skarbczyk, a przy nawie kaplica pw. Matki Boskiej Różańcowej oraz pięcioboczna przybudówka $z$ kruchtą w przyziemiu i składzikiem na piętrze. Druga kaplica, dedykowana św. Annie, usytuowana jest od południa. Do kościoła przylega od zachodu masywna czworoboczna wieża, ukończona w 1624 r. Przed nią znajduje się przybudowana w 1894 r. kruchta ${ }^{14}$.

Publikowany poniżej dokument zawiera dość dokładny opis położenia, wyglądu i stanu kościoła parafialnego w połowie XIX stulecia, a także jego najbliższego otoczenia (dzwonnica, cmentarz przykościelny). Wynika $z$ niego, że świątynia miała bogaty wystrój i wyposażenie wnętrza, na które składały się: ołtarz główny $z$ cudowną figura Pana Jezusa Ukrzyżowanego, pięć ołtarzy bocznych (w tym nieistniejący dziś ołtarz pw. św. Antoniego), dwa chóry, marmurowa chrzcielnica, ambona, konfesjonały, stalle, ławki oraz liczne obrazy. Była też dobrze zaopatrzona w naczynia liturgiczne, szaty i inne paramenty. Inwentarz wymienia: monstrancje srebrna pozłacana, zdobioną wizerunkami Najświętszej Marii Panny i św. Mikołaja; dwa relikwiarze srebrne, w tym jeden $z$ relikwiami drzewa Krzyża Świętego; pięć kielichów srebrnych wyzłacanych; sześć paten; trzy puszki na komunikanty; trybularz srebrny z łódka i łyżeczką; dwa krucyfiksy; naczynie na oleje święte; srebrną tacę $z$ dwiema ampułkami; siedem lichtarzy mosiężnych i 20 cynowych; lampę srebrną z sześcioma łańcuszkami. Oprócz tego odnotowano: 10 wotów srebrnych i takie samo perizonium na wielkim ołtarzu; srebrna sukienkę na obrazie Matki Boskiej oraz trzy korony nad

${ }^{13}$ Por. L. Łętowski, Katalog biskupów, prałatów i kanoników krakowskich, t. II (Biskupi krakowscy), Kraków 1852, s. 162-169; B. Ku mor, Dzieje diecezji krakowskiej do roku 1795, t. I, Kraków 1998, s. 520-521; S. A chrem czyk, R. Marchwiński, J. Przeracki, Poczet biskupów warmińskich, Olsztyn 1994, s. 125-127; P. Nit e cki, Biskupi Kościoła w Polsce w latach 965-1999, Warszawa 2000, s. 458.

${ }^{14}$ J. Wiśniewski, op. cit., s. 118-119; E. Kosik, op. cit., s. 63; C. Hadamik, D. Kalina, E. Traczyńs ki, op. cit., s. 176-177; Katalog zabytków sztuki w Polsce, t. III (Województwo kieleckie), red. J.Z. Łoziński, B. Wolff, z. 3 (Powiat jędrzejowski), oprac. T. Przypkowski, Warszawa 1957, s. 18. 
statuami Maryi, Pana Jezusa i św. Anny. Ujęto w spisie: tackę blaszaną i dwa kociołki na wodę święconą, dwie formy z żelaza do pieczenia opłatków; taką samą liczbę „cyrkularzów” na komunikanty; pięć feretronów $z$ obrazami; 12 dużych choragwi „różnego koloru i materii”, pięć małych i jedna pogrzebową; baldachim „materialny $z$ frędzlami szychowymi"; trzy dzwony z 1655 r. i jeden z 1639; sygnaturkę na kościele oraz 10 dzwonków ołtarzowych.

Opisano ogółem 19 ornatów białych, 15 czerwonych, pięć fioletowych, dwa zielone i sześć czarnych, cztery dalmatyki w różnych kolorach, dziewięć kap oraz dwie infuły biskupie. Wyszczególniono ponadto dziewięć alb, dwie komże dla księży i cztery dla ministrantów, dwa paski do alb, 13 humerałów, umbraculum, 60 obrusów na ołtarze, dwie sukienki na puszki, 16 różnych firanek, antepedium, 17 ręczników do ołtarza i cztery do lawaterza, sześć efodów, a $z$ bielizny kielichowej 10 puryfikaterzy, 33 korporały oraz kilka welonów (velów), palk i burs. W końcowej, niepublikowanej tu części opisu znalazł się wreszcie wykaz ksiąg i dokumentów kościelnych przechowywanych w bibliotece parafialnej. Obejmuje on ponad 120 prac $z$ zakresu religii i teologii, głównie w języku łacińskim, a także 83 dokumenty (m.in. zaginiony dziś akt erekcji świątyni parafialnej, prezentę na probostwo małogoskie dla ks. Jakuba Biedy Chrostkowica oraz przywileje monarsze: Kazimierza Wielkiego z 1343 r., Władysława Jagiełły z 1403 r. i Augusta II Sasa z roku 1724).

Omawiane źródło przynosi również ważne informacje na temat stanu kościoła i dzwonnicy. Oba obiekty wymagały „spiesznej reperacji”. Należało przeprowadzić remont zewnętrzny i wewnętrzny świątyni, sprawić nowe posadzki i okna, zmienić pokrycie dachu nawy i prezbiterium, jak również naprawić dach na wieży kościelnej, który „lada dzień grozi niebezpieczeństwem zawalenia się”. Reperacji wymagał zegar na wieży („zupełnie nieczynny”), schody na chór i wieżę oraz „odstrojone i zdezelowane” organy. Wszystkie ołtarze trzeba było odmalować i na nowo pozłocić (ołtarz pw. św. Mikołaja tak dalece był zniszczony, „iż go zupełnie rozeznać nie można”). Odnowienia potrzebował też mur okalający cmentarz przykościelny i drewniana dzwonnica. 
Edycja dokumentu została opracowana zgodnie $z$ wymogami instrukcji wydawniczej ${ }^{15}$. Zmodernizowano więc pisownię źródła, zachowując jednak jego cechy językowe. Poprawiono także interpunkcję, głównie przez dodanie przecinków i kropek kończących zdanie $\mathrm{w}$ miejsce myślników stosowanych w podstawie wydania. Dwukropek, jako znak kończacy skrót, zamieniono na kropkę. Samogłoski „,", „y” oraz spółgłoskę „j” oddano zgodnie $z$ aktualnie obowiąującymi zasadami. To samo tyczy się stosowania litery „ó”. Podwojone głoski „ff”, „1l”, „mm” i „pp” zastapiono pojedynczymi, np. w słowach „effecta”, „stella”, „massyw”, „apparaty”. Wstawiano również - tam, gdzie jest to wymagane - litery diakrytyzowane, takie jak „ę", „ó”, „śs”, rzadziej „ż”. Uwspółcześniono pisownię wyrazów zakończonych w rękopisie na -em i -emi, np. „zielonem”, „sosnowemi” zmieniono na „zielonym”, „sosnowymi”. Usunięto literę „x”, zastępujac ją dwuznakiem „ks” (np. w słowach „axamitny”, „krucyfix”). Wyrazy "sychowy” i „wrzeciąz" oddano zgodnie $z$ regułami dzisiejszej pisowni jako „szychowy” i „wrzeciądz". Wobec niekonsekwencji spisujacego inwentarz w stosowaniu słowa „ksiądz", które było skracane do "X” lub zapisywane w pełnej formie jako „Xiądz”, zastosowano skrót w każdym przypadku. Również zgodnie $z$ obecna praktyką użyto wielkich liter. Wyrazy, które odbiegają od współczesnej pisowni, a nie zostały poprawione przez wydawcę, opatrzono skróconym sic w nawiasie kwadratowym [s] dla upewnienia czytelnika o zgodności tekstu wydanego $z$ podstawą. $\mathrm{W}$ takich samych nawiasach ujęto poczatek danej strony w oryginale, rozwiązano skróty, zaznaczono miejsca nieczytelne, wreszcie uzupełniono opuszczone przez pisarza litery. W źródle występuje zmiana ręki oraz dopiski na marginesie i pod tekstem. Wszystko to zostało oznaczone przypisami tekstowymi. W przypisach rzeczowych objaśniono trudniejsze terminy $z$ zakresu włókiennictwa. Zachowano podkreślenia wyrazów, a także układ tekstu znajdujący się w rękopisie. W edycji występują następujące skróty: S. - Święty, Święta; X. - Ksiądz; W.X. - Wielmożny Ksiądz.

${ }^{15}$ Instrukcja wydawnicza dla źródeł historycznych od XVI do połowy XIX wieku, red. K. Lepszy, Wrocław 1953. 


\section{Opisanie kościoła i jego ozdób}

Or.: Archiwum Diecezjalne w Kielcach, Małogoszcz. Dokumenty różne z XIX wieku (luzem, nieuporządkowane), sygn. IIPM-I/6, k. 49v-59.

[k. 49v] Kościół parafialny w mieście Małogoszczu pod tytułem Najświętszej Marii Panny Wniebowzięcia położony jest w tyle miasta przy ulicy Włoszczowskiej, w okręgu osobnym cmentarza niewiele rozległego, murem potrzebującym wielkiej reperacyi w około obwiedzionego. Na cmentarzu znajduje się dzwonnica od strony wschodniej, w bliskości bramy wystawiona, na dziewięciu słupach dębowych, boki dzwonnicy tarcicami obite, dach kryty gontem, cała dzwonnica potrzebuje znacznej reperacyi. Wśród cmentarza znajduje się kościół w krzyż postawiony, $z$ kamienia wapiennego masyw murowany, $z$ wieżą znacznie nad kościół wzniesiona, nad wierzchem tej wieży znajduje się krzyż żelazny ajuż znacznie pochylonya, wewnątrz wieży umieszczony jest zygar [s] bijacy godziny, lecz dziśs zupełnie zniszczony. Wierzch wieży tak jest zniszczony, iż lada dzień grozi niebezpieczeństwem zawalenia się. ${ }^{a}$ Cały kościół dachówka jest pokryty, lecz dach $z$ powodu przegnicia krokiew zupełnego potrzebuje przestawienia, $z$ powodu zacieków cały kościół wewnątrz i zewnątrz spiesznej potrzebuje reperacyia. Wejścia do tego kościoła sa dwa $^{\mathrm{b}}$, pierwsze od strony zachodniej pod wieżą formująca kruchtę, drugie od strony północnej przez druga kruchtę. W wejściu pierwszym znajduje się kruchta przymurowana do wieży, z której wchodzi się do kościoła drzwiami podwójnymi sosnowymi, żelazną blacha i prętami żelaznymi krzyżowo opatrzonymi, na czterech zawiasach i hakach żelaznych umocowanymi, zamykającymi się na zasuwę drewnianą i kłódkę - drzwi te bardzo źle są osadzone i $z$ tego powodu szparami wielki przeciag $[k .50]$ w kościele sprawiaja. Przy wchodzie jest próg $z$ kamienia ciosowego, wchodząc do kościoła przez uformowany pod wieża przysionek, w którym znajduje się posadzka $z$ kamienia ciosowego, bardzo zła, pod chórem trzy gradusy ${ }^{1}$ częścia $z$ drzewa, częścią $z$ kamienia ułożone. Chór drewniany na dwóch filarach $z$ drzewa sosnowego wspierajacy się, na którym umieszczony jest organ średniej wielkości, o czterech głosach drewnianych, a pięciu $\mathrm{w}$ nowych, $z$ trzema miechami, cały organ ze wszystkim odstrojony i zdezelowany wymaga spiesznej reperacyi.

\footnotetext{
a-a Zakreślone ołówkiem.

b Dopisane pod wierszem ołówkiem: „trzy”.

${ }^{1}$ Czyli stopnie.
} 
Drugi wchód od strony północnej jest przez kruchtę do kościoła przymurowaną, do której wchodzi się drzwiami podwójnymi, sosnowymi, $z$ okienkami na kłódkę zamykanymi. W kruchcie jest posadzka $z$ cegły, ${ }^{c} z u p e ł n i e ~ z ł a c$, po prawej stronie znajduja się drzwi $z$ drzewa sosnowego na hakach i zawiasach żelaznych, $z$ zamkiem, wrzeciądzem i skoblami. Za tymi drzwiami znajduja się schody na chór $\mathrm{w}$ złym stanie, $z$ chóru wchodzi się schodami zupełnie zdezelowanymi na wieżą $[s]^{\mathrm{d}} ; z$ kruchty tej wchodzi się do kościoła drzwiami sosnowymi, blachą i prętami żelaznymi krzyżowo opatrzonymi, na trzech zawiasach i hakach żelaznych, $z$ antaba żelazną w środku odrzwi, z zamkiem dużym żelaznym na trzy rygle się zamykającym. Wchodząc do kościoła, nad drzwiami dopiero wspomnionemi [s] znajduje się chórek mały drewniany ${ }^{\mathrm{e}}$, ana dwóch słupach drewnianych wsparty i $z$ chórem większym się łączący, chórek ten znacznie jest zdezelowany ${ }^{a}$ ${ }^{f} \mathrm{~W}$ kościele jest posadzka $z$ kamienia ciosowego zupełnie $z \nmid a^{\mathrm{f}}$, po obydwóch stronach kościoła znajduja się kaplice, jako to: po prawej stronie kaplica Stej Anny, a po lewej kaplica Matki Boskiej, w tych kaplicach sa posadzki częścią z kamienia, częścią z cegły ułożone, zupełnie złe ${ }^{g}$. Do prezbiterium [k. 50v] wchodzi się przez jeden gradus kamienny, na którym znajduje się posadzka kamienna, także $z \nmid a^{\mathrm{h}}$, dalej ku wielkiemu ołtarzowi jest gradus murowany, następnie posadzka murowana wymagająca przerzucenia ${ }^{i}$. W całym korpusie kościoła znajduje się dziesięć okien większych, podłużnych i dwa mniejsze w kaplicach, szkło po większej części gradem wybite, a rama [s] przegniłej.

W kaplicy $\mathrm{S}^{\mathrm{tej}}$ Anny, po prawej stronie ołtarza, znajdują się drzwi do skarbczyka poza ołtarzem będacego, drzwi sa drewniane, blachą i żelaznymi prętami krzyżowo okute, na dwóch zawiasach żelaznych, z zamkiem, wrzeciądzem i skoblem, w skarbczyku posadzka $z$ cegły zła.

Po lewej stronie prezbiterium [w] bliskości wielkiego ołtarza jest zakrystia, do której są drzwi żelazne $z$ prętami żelaznymi,

c-c Podkreślone ołówkiem, powyżej nadpisano: „Obecnie murowana $z$ kamienia”.

d Nadpisano ołówkiem: „obecnie nowymi”.

e Nadpisane nad wierszem ołówkiem: „obecnie z kamienia(?)”.

f-f Podkreślone ołówkiem.

g Nadpisane nad wierszem ołówkiem: „obecnie zupełnie dobre”.

h Nadpisane nad wierszem ołówkiem: "obecnie nowa”.

"Nadpisane nad wierszem ołówkiem: „obecnie nowa”.

j Nadpisane nad wierszem ołówkiem: „obecnie ramy nowe - okna zupełnie dobre". 
w kratę opatrzone, na dwóch zawiasach, hakach żelaznych, przy nich znajduje się wielki zamek o jednym ryglu - wrzeciądz i skobel do zamykania na kłódkę. Wchód do zakrystii jest przez próg kamienny, w zakrystii posadzka $z$ cegły zła. Okno w złym stanie, $z$ kratą żelazna $a^{k}$. Po prawej stronie w zakrystii sa drzwiczki małe, drewniane, na dwóch zawiasach żelaznych, [ze] skoblem i wrzeciądzem, prowadzące do małego skarbczyka, w którym jest posadzka $z$ kamienia $z^{\prime}{ }^{1}$, po lewej zaś stronie w zakrystyi, po trzech gradusach murowanych, jest wejście do skarbca zamykanego na drzwi drewniane, blacha, prętami żelaznymi okute, na dwóch zawiasach i hakach żelaznych, $z$ zamkiem, dwiema wrzeciądzami i skoblami, w skarbcu tym jest podłoga $z$ desek zła i okienko $z$ dwoma kratami żelaznymi ${ }^{\mathrm{m}}$.

\section{Wewnetrzne ozdoby kościoła}

1. Ołtarz wielki. Do wielkiego ołtarza wchodzi się po trzech ${ }^{\mathrm{n}}$ [k. 51] gradusach murowanych, mensa murowana, na niej wielki ołtarz drewniany z figura Pana Jezusa Ukrzyżowanego, cały ołtarz jest snycerska robota wyrobiony i złocony, lecz wymaga zupełnego odmalowania i złocenia ${ }^{\circ}$. Cyborium drewniane, stolarska robota ordynarna wyrabiane, potrzebuje zupełnego odświeżenia, na wierzchu cyborium sa dwie figury: S. Piotra i Pawła ${ }^{\mathrm{p}}$.

[2.] Ołtarz S. Jakuba Apostoła. Idąc od wielkiego ołtarza, po prawej stronie znajduje się ołtarz pomniejszy, do którego wchodzi się po dwóch gradusach kamiennych, bardzo niewygodnych. Mensa kamienna, na której jest ołtarz drewniany - obok obrazu S. Jakuba, po dwóch stronach, między małymi kolumnami malarsko złoconymi, znajdu[ja] się dwie figurki świętych. Cały ołtarz potrzebuje zupełnego przestawienia i odnowienia ${ }^{\mathrm{r}}$.

k Nadpisane nad wierszem ołówkiem: „obecnie nowe, obecnie w dobrym”.

${ }^{1}$ Dodane na marginesie ołówkiem: „Skarbczyk ten przerobiony na przedsionek”.

m Nadpisane nad wierszem ołówkiem: „Obecnie skarbiec zupełnie przerobiony, podłoga dębowa, schody kamienne".

" Dopisane pod wierszem ołówkiem: „obecnie po 4”.

- Nadpisane nad wierszem ołówkiem: „obecnie odnowione(?)”.

p Dopisane $z$ boku ołówkiem: „Cyborium obecnie nowe, odpowiednio do całego ołtarza złocone".

${ }^{r}$ Dopisane $z$ boku ołówkiem: „zupełnie odnowiony - obraz nowy”.

u W źródle: „znajdującym”. 
[3.] Ołtarz S. Mikołaja. Naprzeciwko ołtarza S. Jakuba jest takiż sam ołtarz S. Mikołaja, znajdujący ${ }^{u}$ się w takimże stanie, jak poprzedni, z tą różnica, że sam ołtarz S. Mikołaja tak jest zdezelowany, iż go zupełnie rozeznać nie możnas

[4.] Ołtarz S. Anny. Znajduje się w kaplicy, wchodzi się do niego po trzech gradusach marmurowych, mensa murowana. Ołtarz drewniany, snycerska robota wyrabiany, wyzłacany, wymaga zupełnego odnowienia. W ołtarzu sa trzy figury złocone, nad którymi znajduja się trzy srebrne koronyt.

[5.] Ołtarz Matki Boskiej. Znajduje się w kaplicy, do której się wchodzi po dwóch gradusach murowanych. Mensa murowana, na tej znajduje się ołtarz malowany o dwóch kolumnach, snycerska robota wyrabianych i wyzłacanych, hakami podziurawionych, a lampami pokopconych [s]. Na obrazie Matki Boskiej przymocowana jest sukienka i korona $z$ blachy $[k .51 v]$ srebrnej, zanieczyszczonej, zasuwa na płótnie malowana $z$ wyobrażeniem S. Wojciecha ${ }^{u}$.

[6.] Ołtarz S. Antoniego. W tej samej kaplicy znajduje się ołtarz mały, do którego jest gradus jeden drewniany, zupełnie zły, mensa drewniana, na tej ołtarz mały $z$ obrazem S So Antoniego na płótnie malowany i sukienka $z$ blachy miedzianej. Ołtarz ten równie jak wszystkie inne wymaga zupełnej reperacyi. W części prezbiterium, idacc od w[ielkiego] ołtarza, po lewej stronie znajduje się ambona drewniana stolarskiej roboty, snycerskiemi sztukami ozdobiona, również w złym stanie, do tej ambony są schodki łączące się $z$ wielka steląv.

\section{Aparaty kościelnew}

[tabela na stronach 336-358]

s Dopisane pod wierszem ołówkiem: „Obecnie odnowiony. Obraz nowy”.

t Dopisane z boku ołówkiem: „odświeżony”.

u Dopisane $z$ boku ołówkiem: „Sukienka nowo odzłocona”.

v Dopisane pod wierszem ołówkiem: „Ołtarz obecnie zupełnie nowy i nowe obrazy".

w Dopisane z boku ołówkiem: „Nota”. 


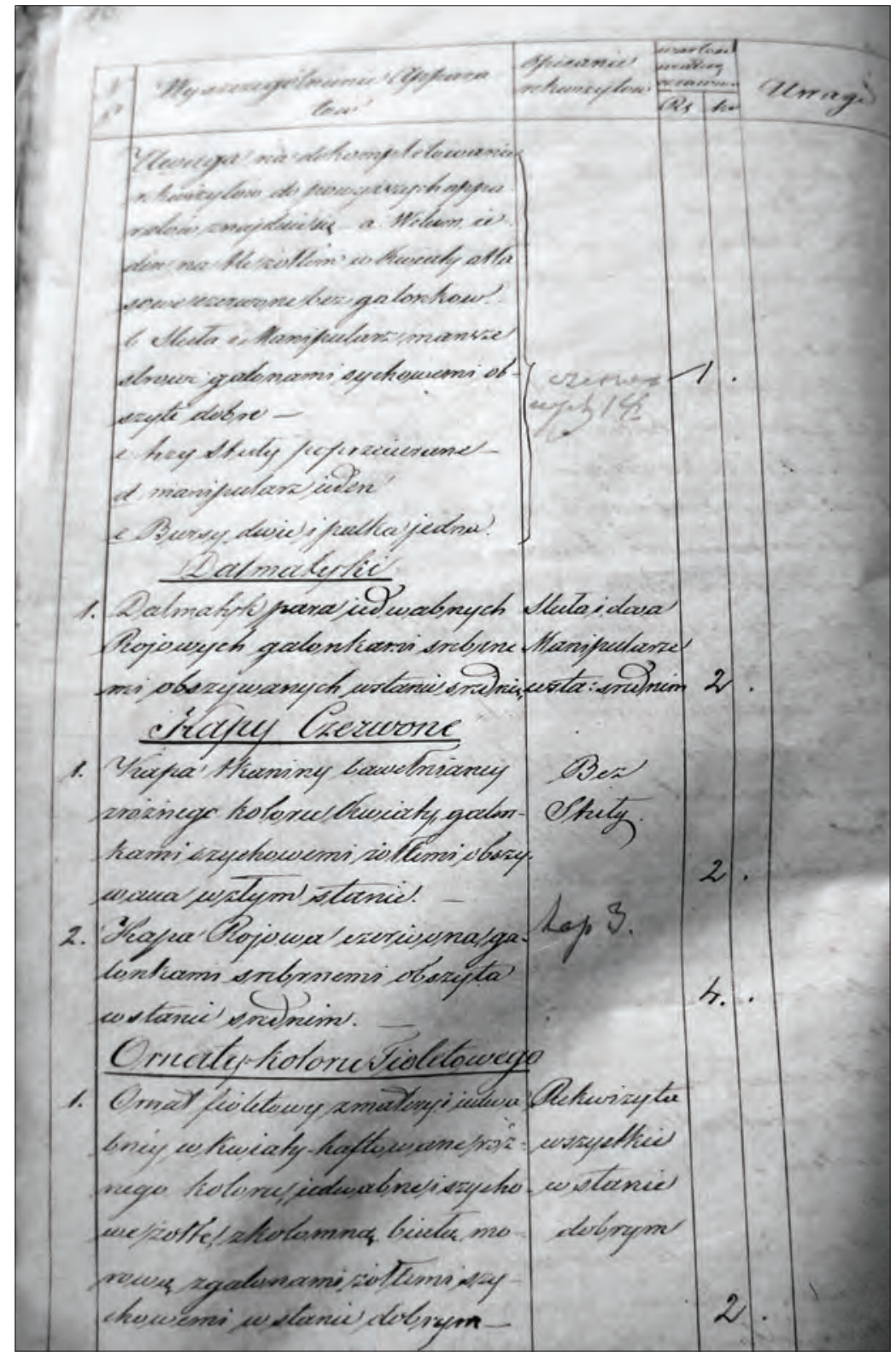

Inwentarz fundi instructi probostwa w Małogoszczu z 1856 r. Fot. M. Karkocha 


\begin{tabular}{|c|c|c|c|c|c|c|}
\hline 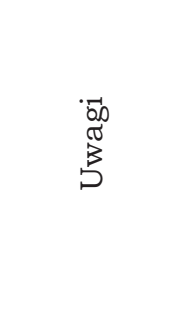 & & 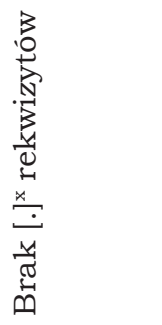 & & & & \\
\hline \multirow{2}{*}{ 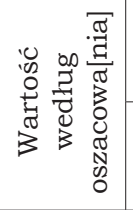 } & & 1 & 1 & ̊ & 1 & 1 \\
\hline & & m & - & - & 0 & in \\
\hline 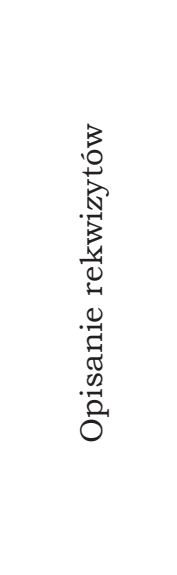 & & 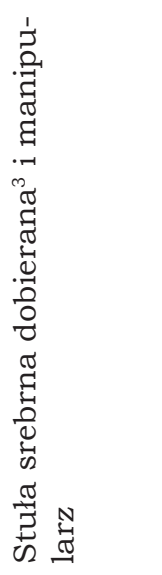 & 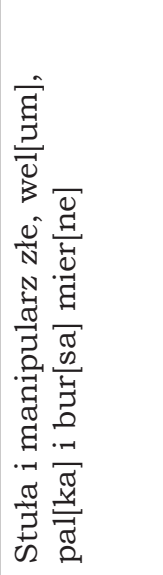 & 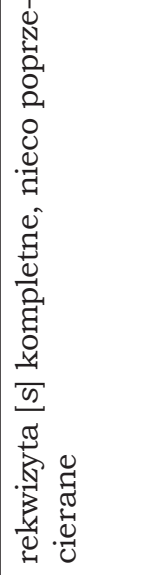 & 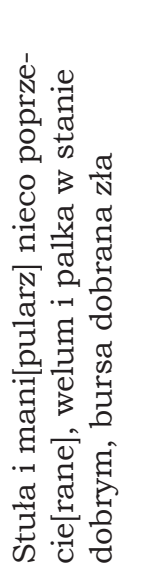 & 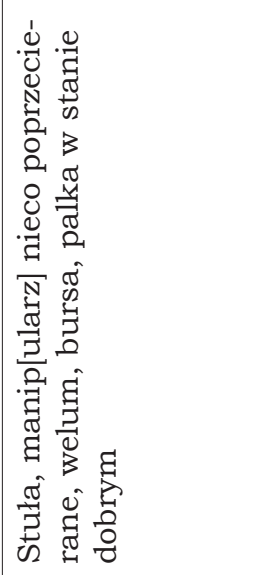 \\
\hline 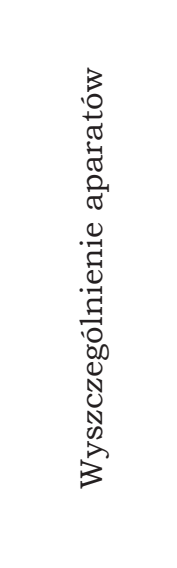 & $\begin{array}{l}\text { od } \\
0 \\
0 \\
0 \\
0 \\
0 \\
0 \\
0 \\
0 \\
0 \\
0 \\
0\end{array}$ & 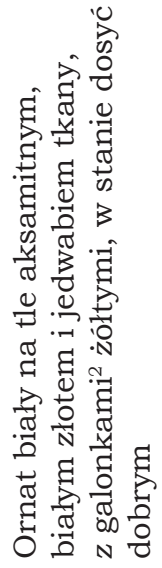 & 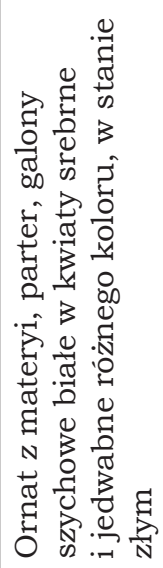 & 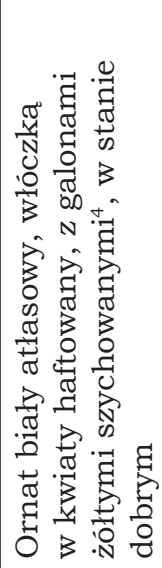 & 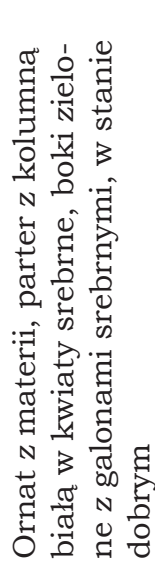 & 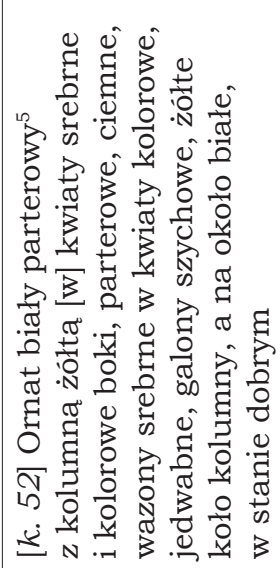 \\
\hline 光点 & & -1 & N & $m$ & t & ما \\
\hline
\end{tabular}


Wystrój i wyposażenie kościoła parafialnego... 337

\begin{tabular}{|c|c|c|c|c|c|c|c|}
\hline & & 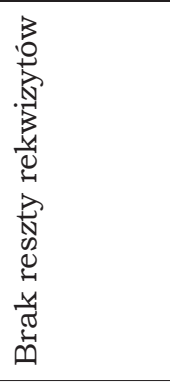 & 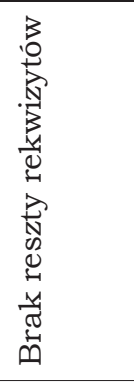 & & 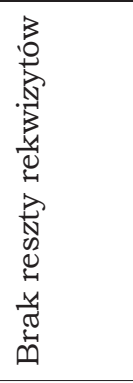 & 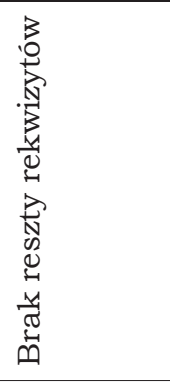 & 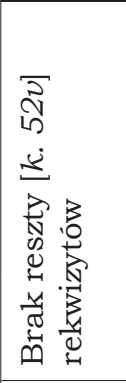 \\
\hline$\stackrel{\sim}{~}$ & 1 & ฉิ & ণ & 1 & $\stackrel{L}{\wedge}$ & $\stackrel{L}{\wedge}$ & $\stackrel{10}{R}$ \\
\hline$\neg$ & $\sigma$ & - & - & - & 1 & 1 & 1 \\
\hline 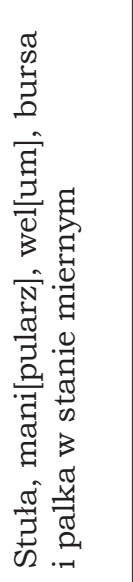 & 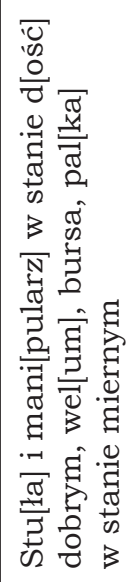 & 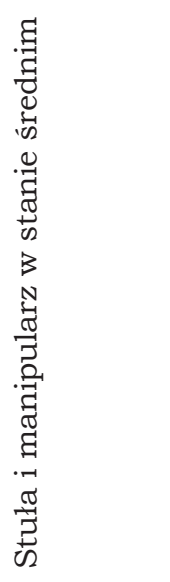 & 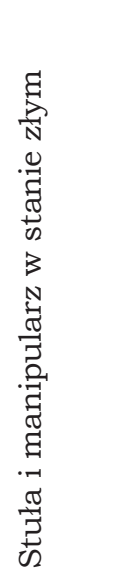 & 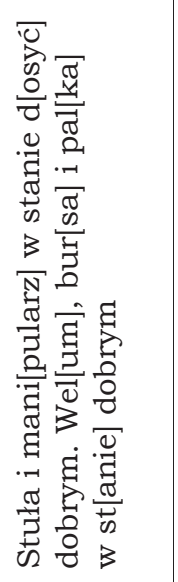 & 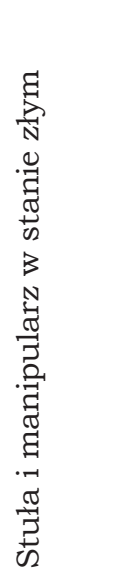 & 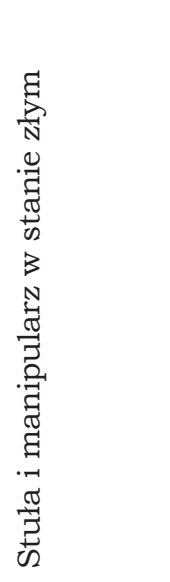 & 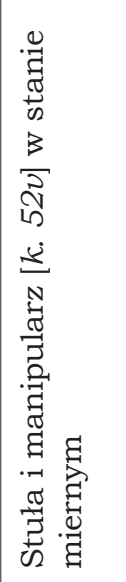 \\
\hline 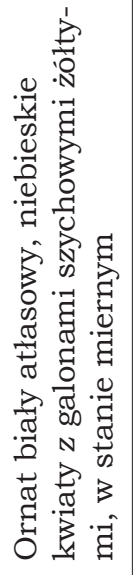 & 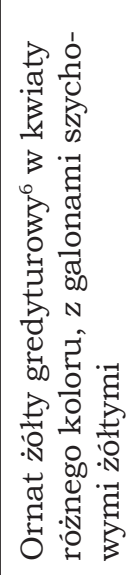 & 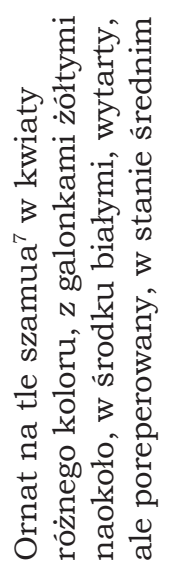 & 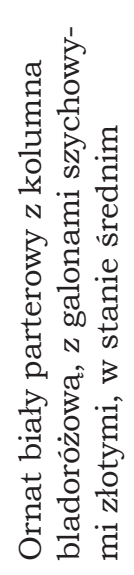 & 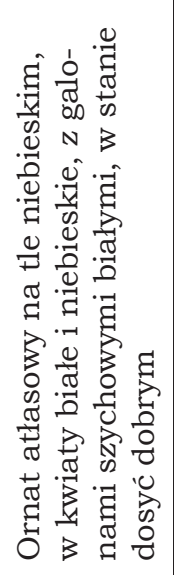 & 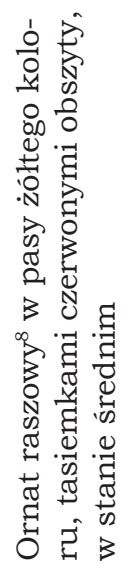 & 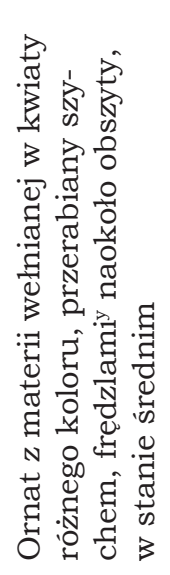 & 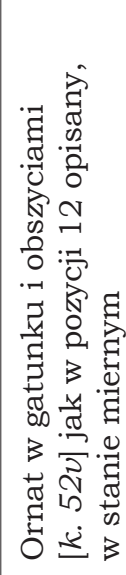 \\
\hline 0 & $\wedge$ & $\infty$ & $a$ & $\stackrel{0}{-}$ & 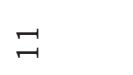 & $\stackrel{\sim}{\sim}$ & $\stackrel{m}{\sim}$ \\
\hline
\end{tabular}




\begin{tabular}{|c|c|c|c|c|c|c|c|}
\hline \multicolumn{2}{|l|}{$\begin{array}{l}50 \\
\widetilde{\sigma} \\
3 \\
5\end{array}$} & \multirow[b]{2}{*}{ \& } & \multirow[b]{2}{*}{ ஓৃ } & \multirow[b]{2}{*}{ ஓి } & \multirow{6}{*}{ | } & & \\
\hline \multirow{2}{*}{ 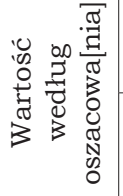 } & مُ & & & & & ㅇํ & 1 \\
\hline & $\tilde{\varkappa}$ & 1 & 1 & 1 & & N & $m$ \\
\hline \multicolumn{2}{|l|}{ 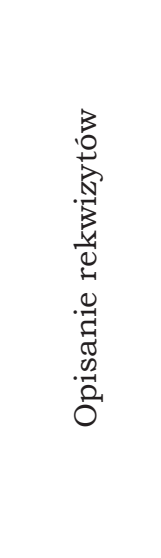 } & 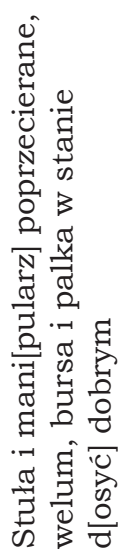 & 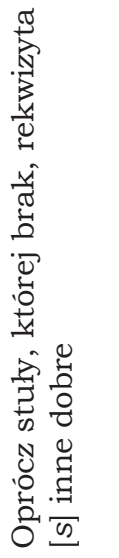 & 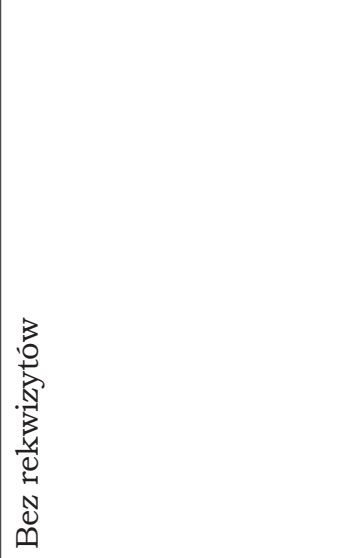 & & 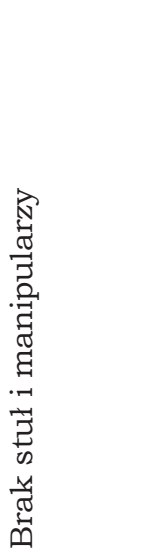 & 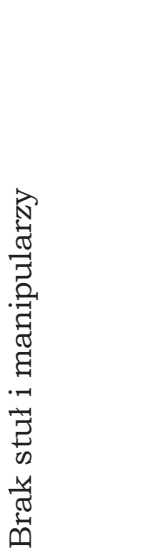 \\
\hline \multicolumn{2}{|l|}{ 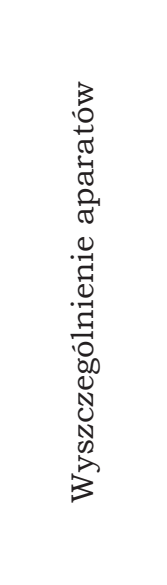 } & 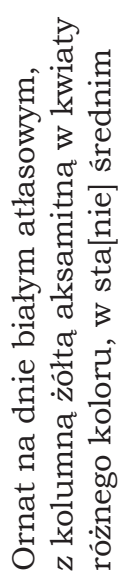 & 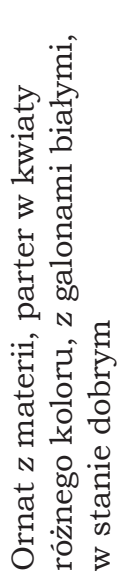 & 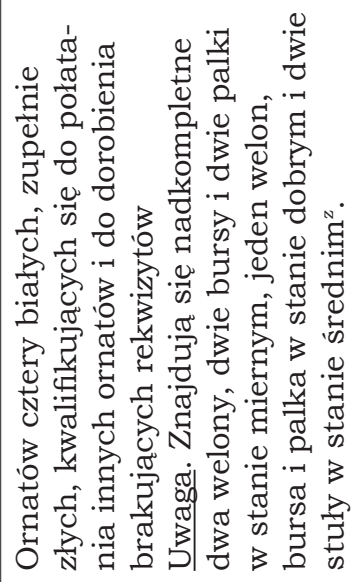 & & 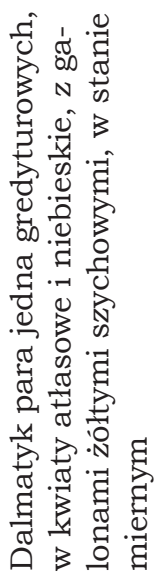 & 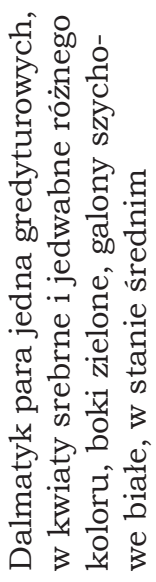 \\
\hline 学空 & & $\stackrel{ナ}{\sim}$ & $\stackrel{10}{\sim}$ & $\stackrel{0}{-1}$ & & $\neg$ & N \\
\hline
\end{tabular}


Wystrój i wyposażenie kościoła parafialnego... 339

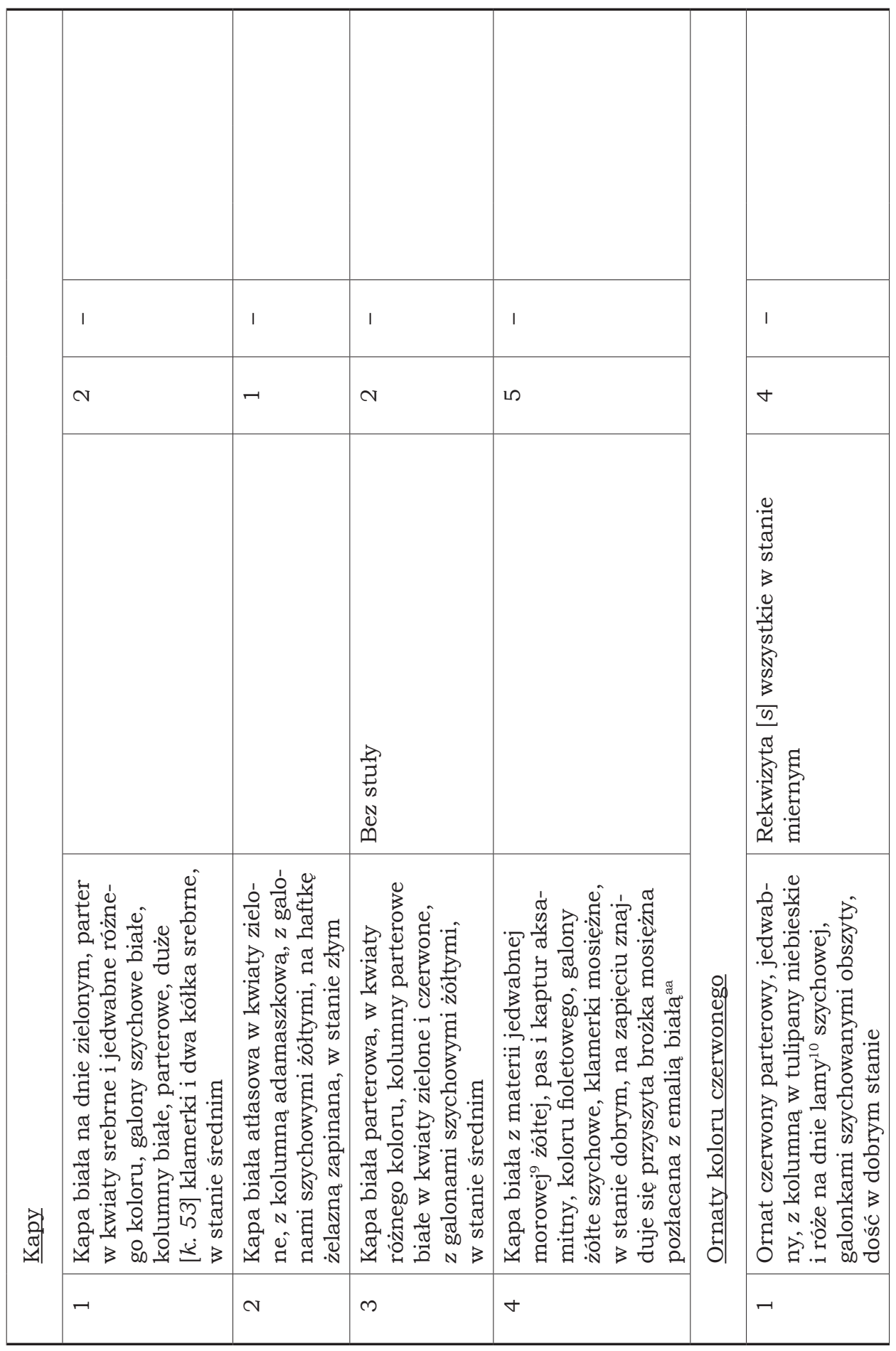




\begin{tabular}{|c|c|c|c|c|c|c|}
\hline \multicolumn{2}{|l|}{$\begin{array}{l}\overrightarrow{50} \\
\bar{\sigma} \\
3 \\
3 \\
5\end{array}$} & & & 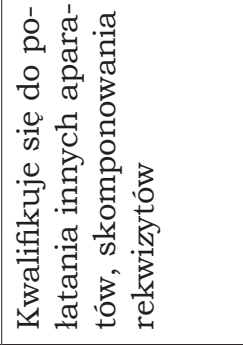 & 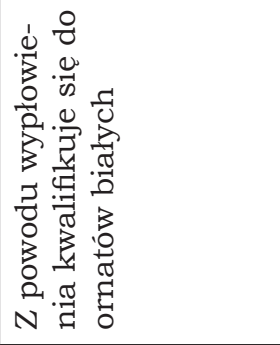 & \\
\hline \multirow{2}{*}{ 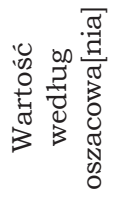 } & $\begin{array}{l}\dot{2} \\
0 \\
0\end{array}$ & 1 & 1 & $\stackrel{\sim}{\wedge}$ & $\stackrel{\mathscr{L}}{\Lambda}$ & 1 \\
\hline & $\stackrel{2}{\sim}$ & $m$ & $\neg$ & 1 & 1 & $\neg$ \\
\hline 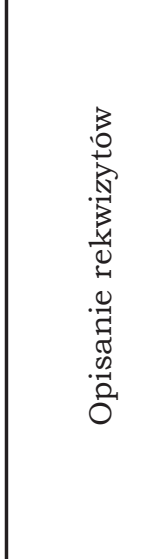 & & 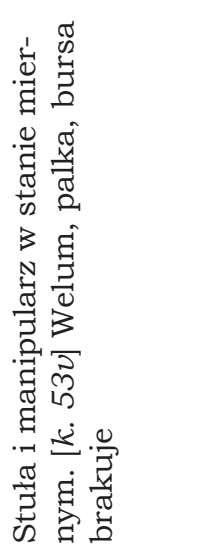 & 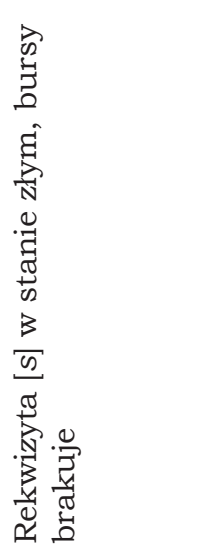 & 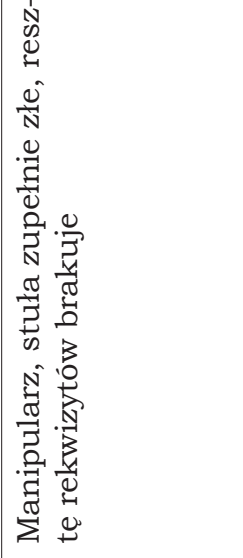 & 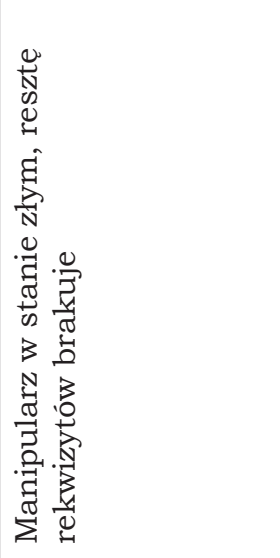 & 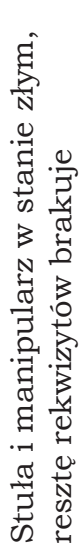 \\
\hline \multicolumn{2}{|l|}{ 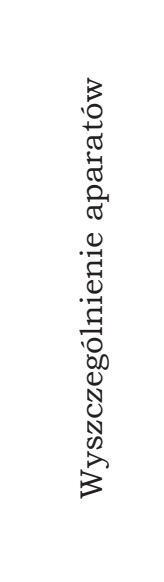 } & 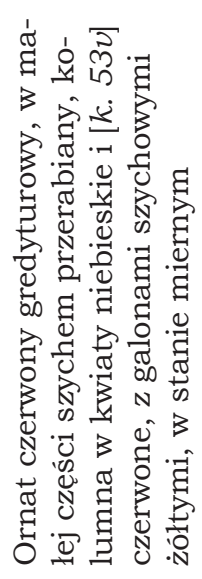 & 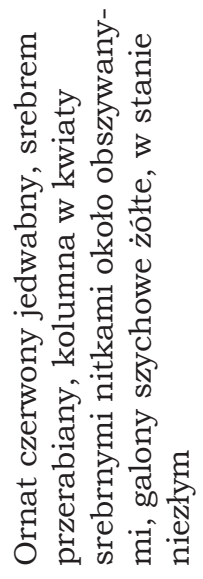 & 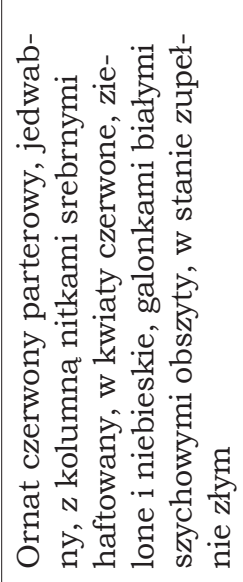 & 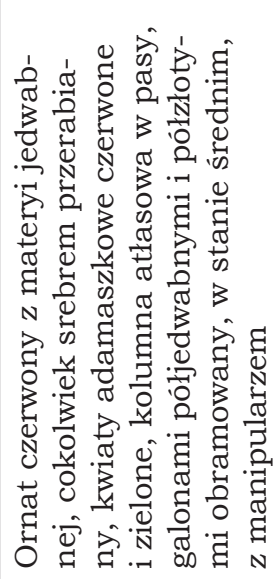 & 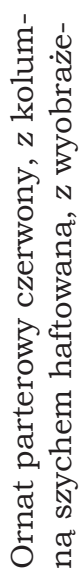 \\
\hline 㝋空 & & N & M & $\sigma$ & L & 0 \\
\hline
\end{tabular}


Wystrój i wyposażenie kościoła parafialnego... 341

\begin{tabular}{|c|c|c|c|c|c|c|}
\hline & & & 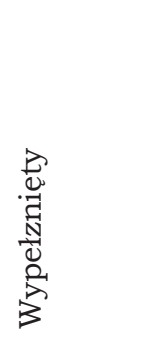 & & 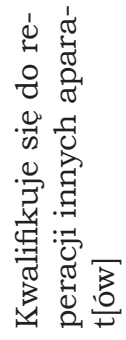 & \\
\hline & 1 & 1 & 1 & 1 & $\stackrel{\llcorner 0}{\sim}$ & ஓे \\
\hline & o & $\sim$ & - & $m$ & 1 & 1 \\
\hline & 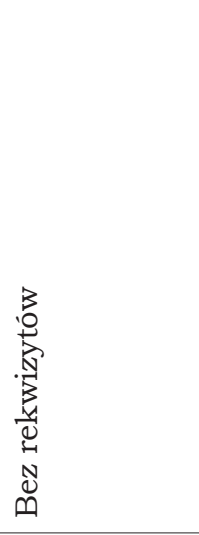 & 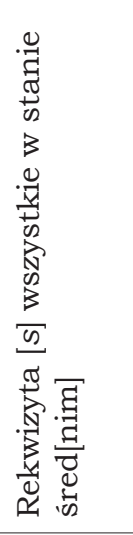 & 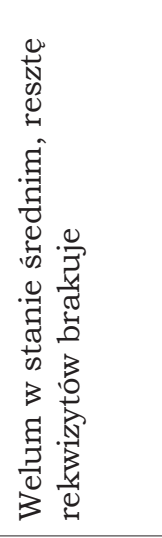 & 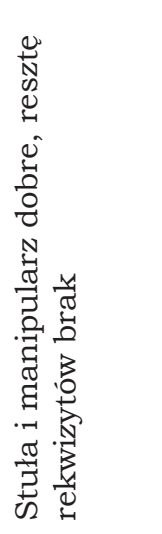 & 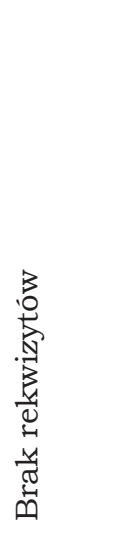 & 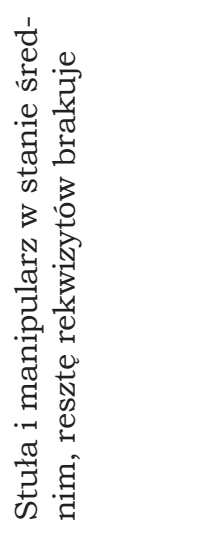 \\
\hline \multirow[t]{2}{*}{ 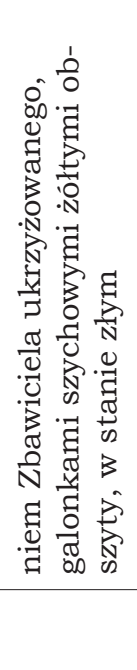 } & 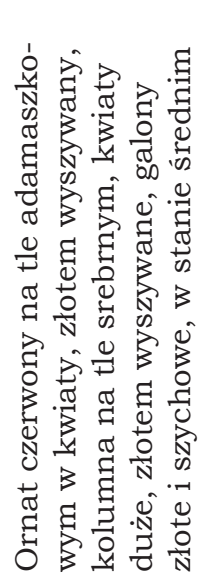 & 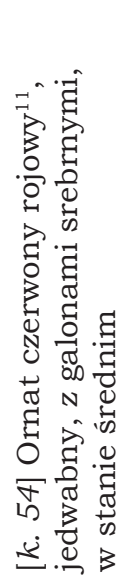 & 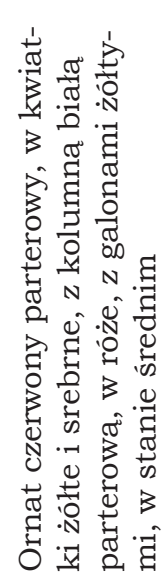 & 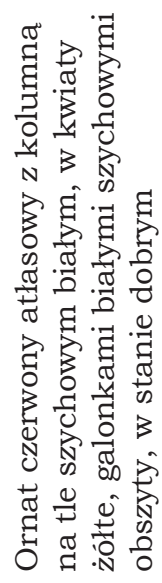 & 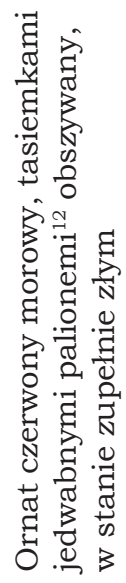 & 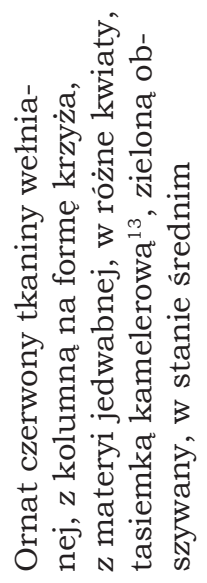 \\
\hline & $\Lambda$ & $\infty$ & $a$ & $\stackrel{\circ}{-}$ & 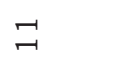 & $\stackrel{\sim}{\sim}$ \\
\hline
\end{tabular}




\begin{tabular}{|c|c|c|c|c|}
\hline $\begin{array}{l}\overrightarrow{b 0} \\
\widetilde{0} \\
\tilde{5}\end{array}$ & & & & \\
\hline \multirow{2}{*}{ 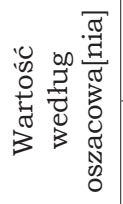 } & $\stackrel{1}{\sim}$ & 1 & 1 & 1 \\
\hline & 1 & $\sim$ & $\sim$ & $\neg$ \\
\hline 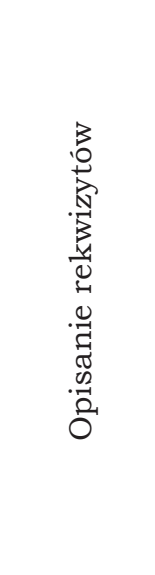 & 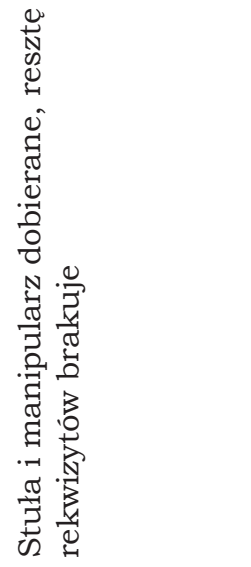 & 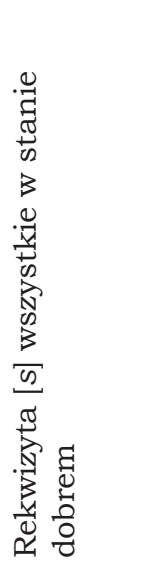 & 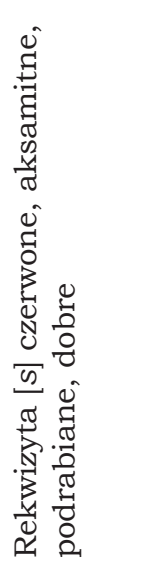 & \\
\hline 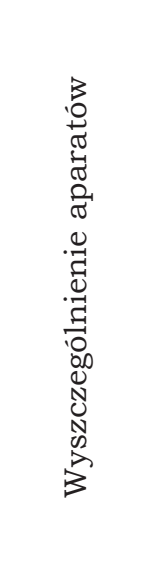 & 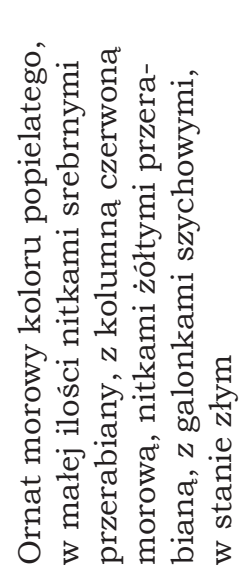 & 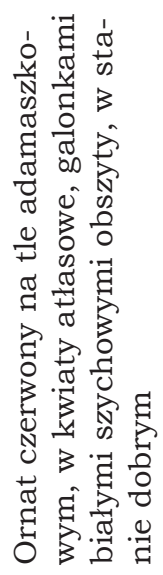 & 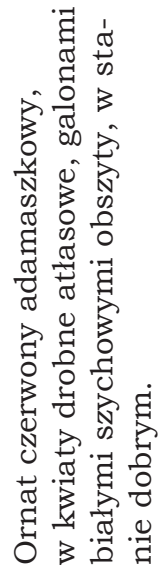 & 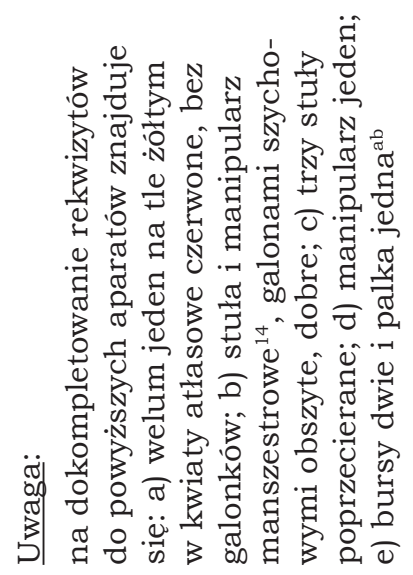 \\
\hline 学蒡 & $\stackrel{M}{\rightarrow}$ & $\stackrel{\Delta}{-}$ & $\stackrel{2}{\rightarrow}$ & \\
\hline
\end{tabular}


Wystrój i wyposażenie kościoła parafialnego... 343

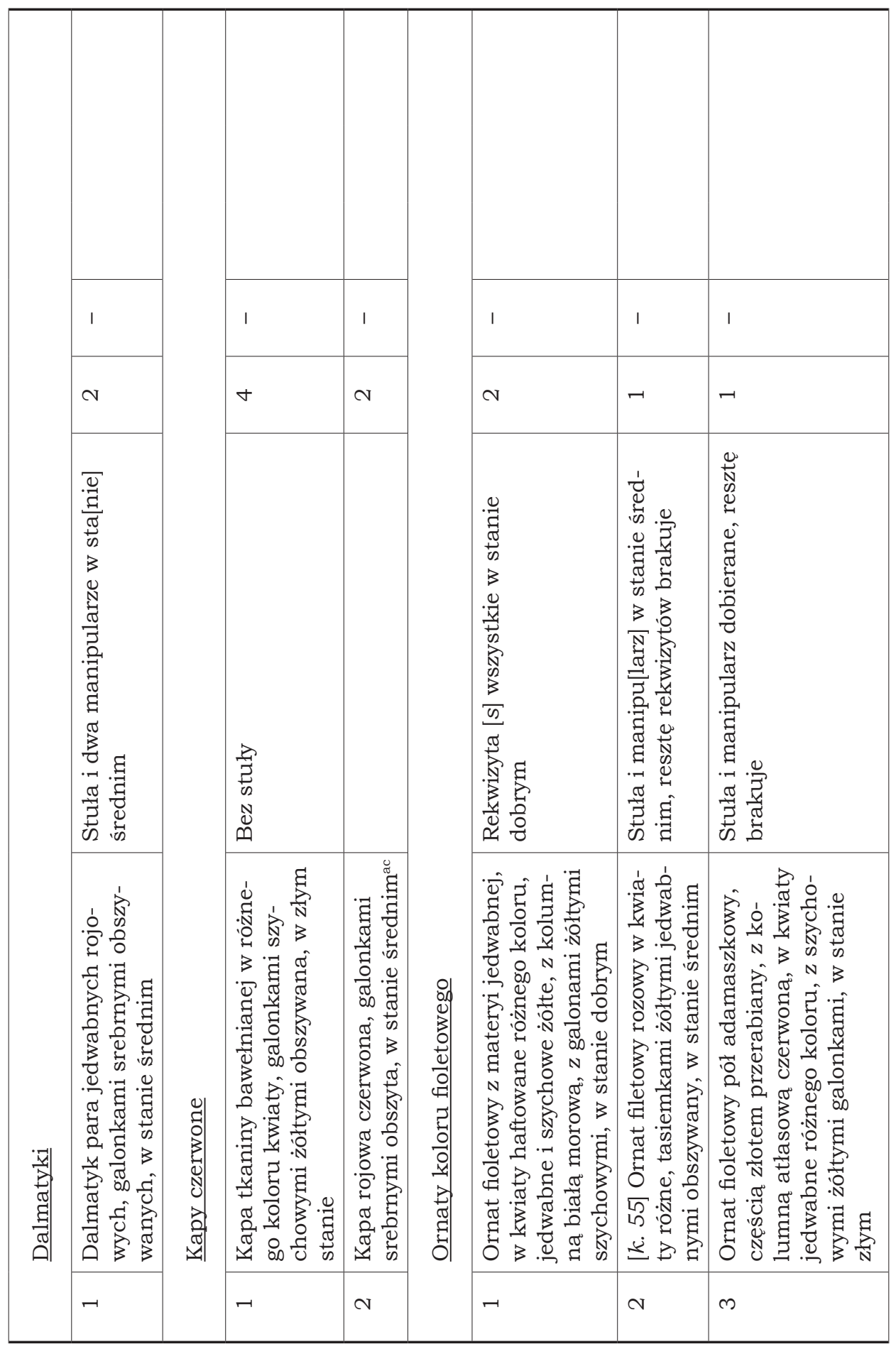




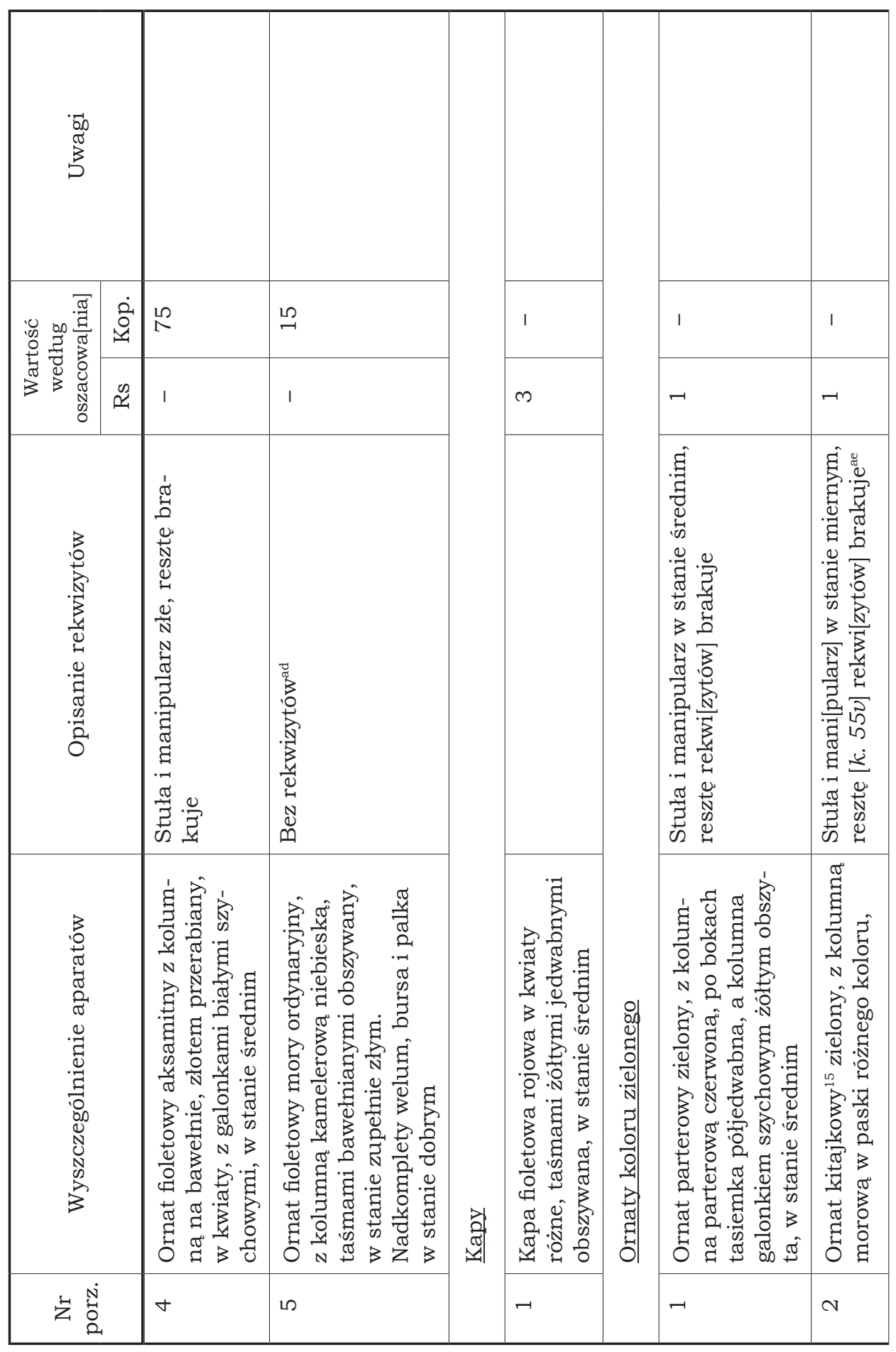


Wystrój i wyposażenie kościoła parafialnego... 345

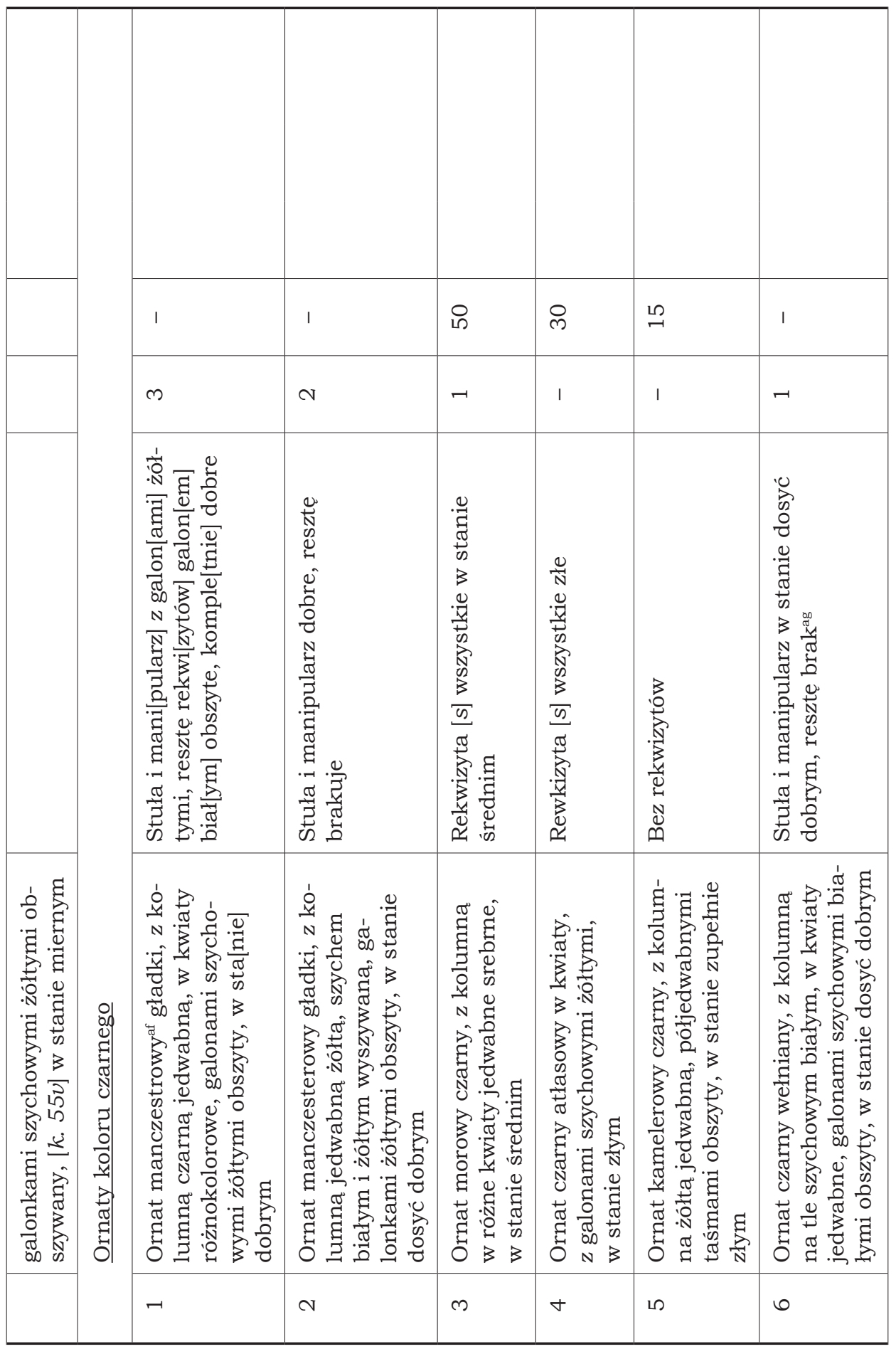




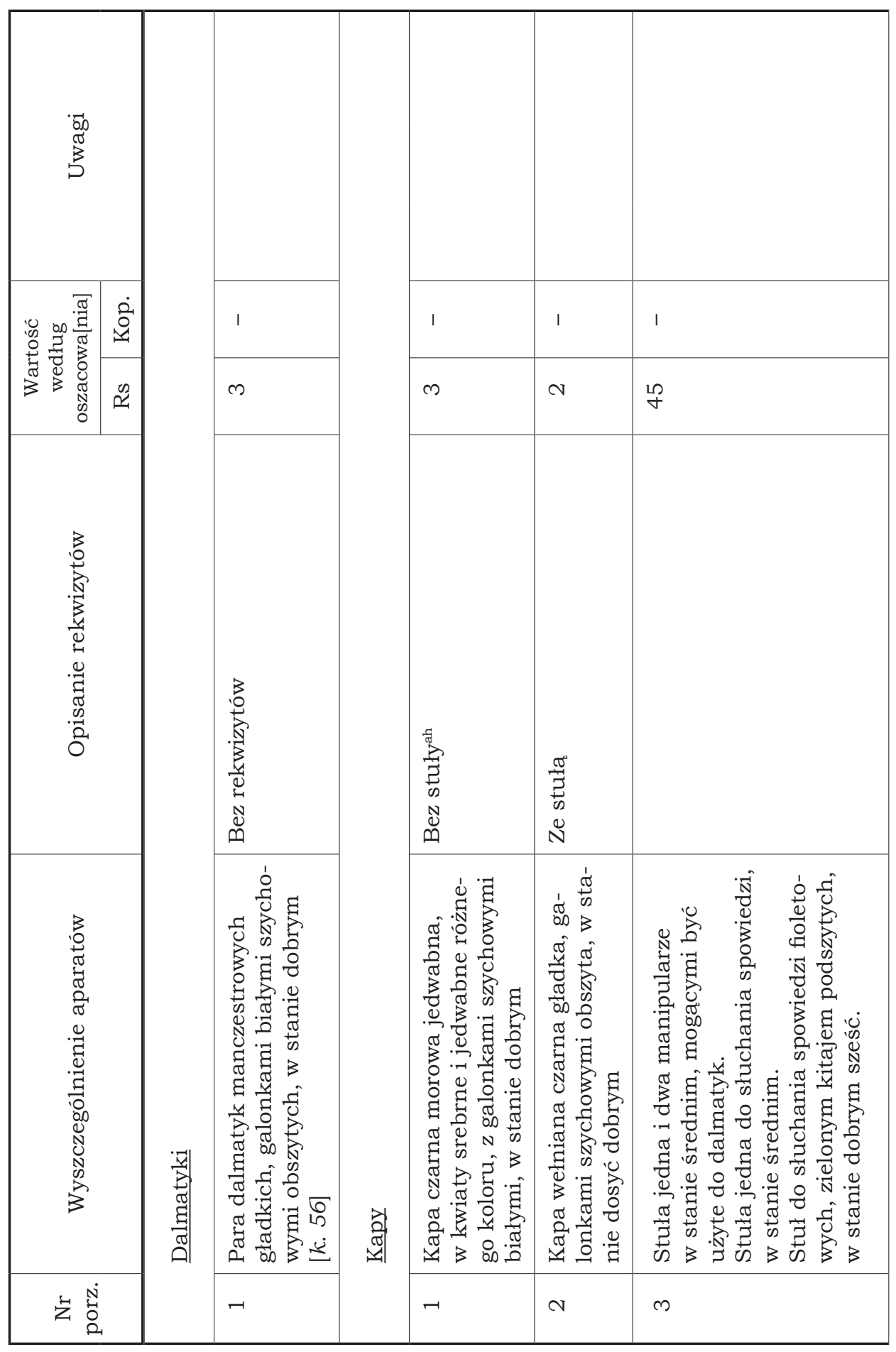


Wystrój i wyposażenie kościoła parafialnego... 347

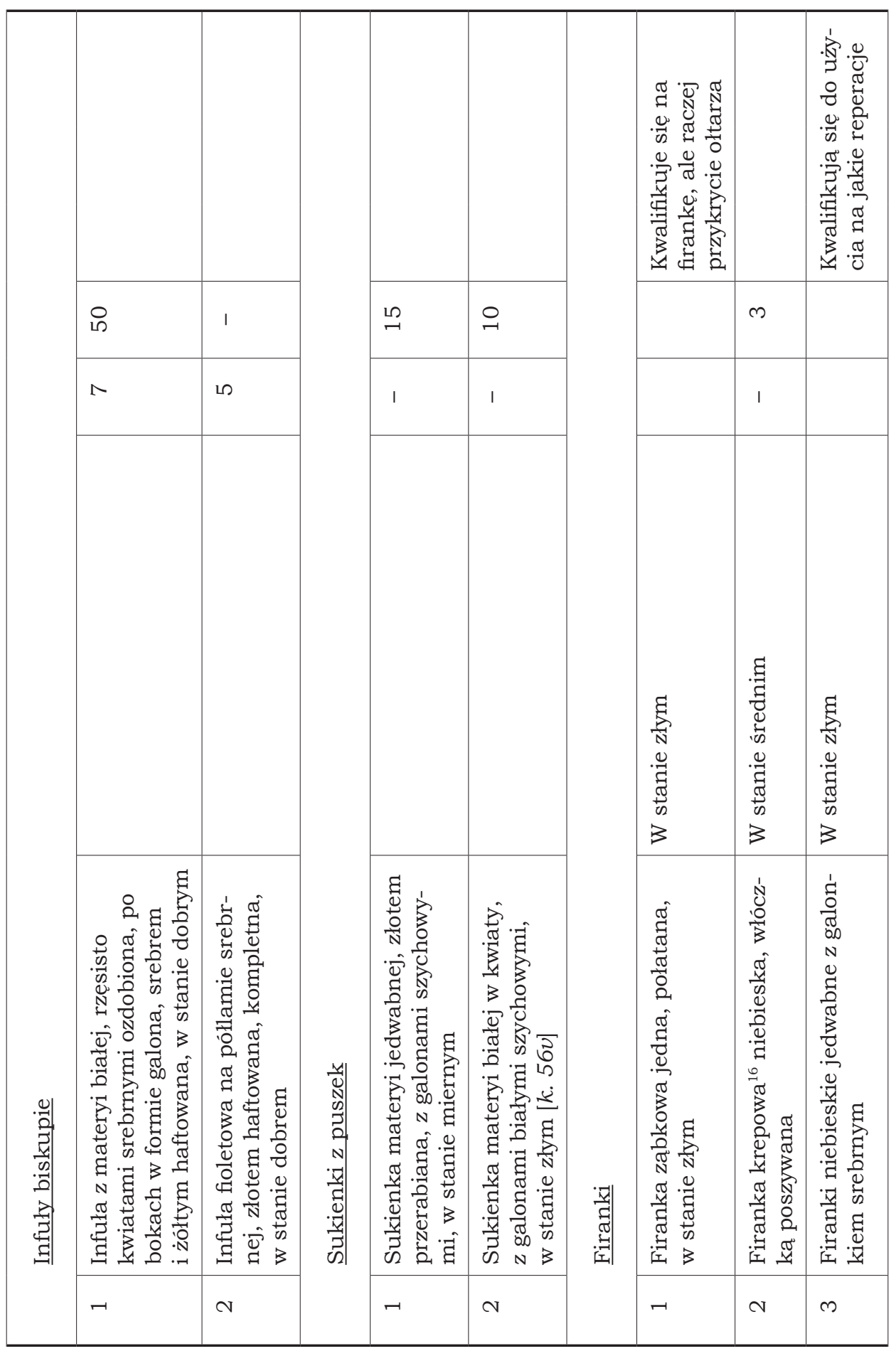




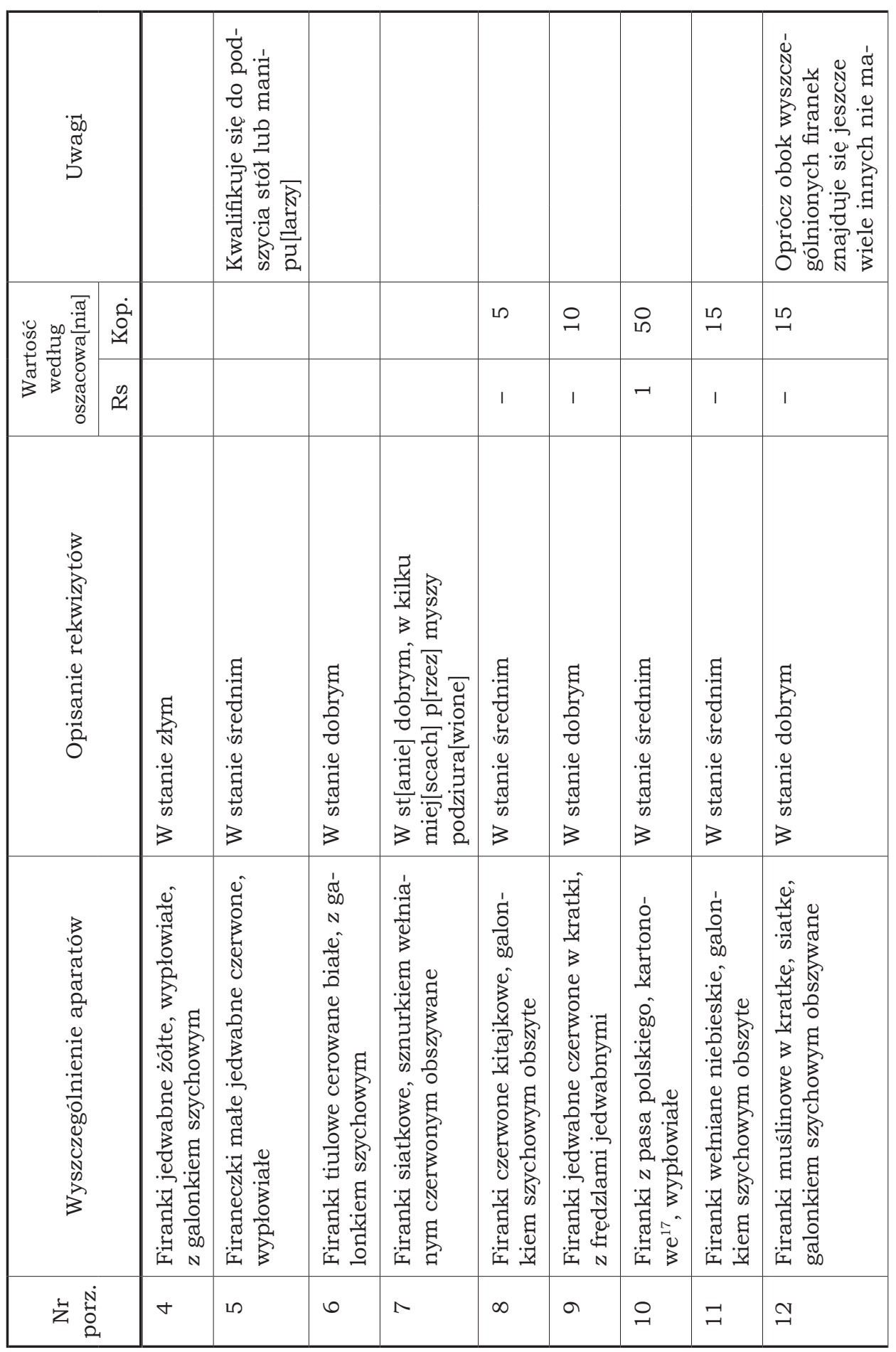


Wystrój i wyposażenie kościoła parafialnego... 349

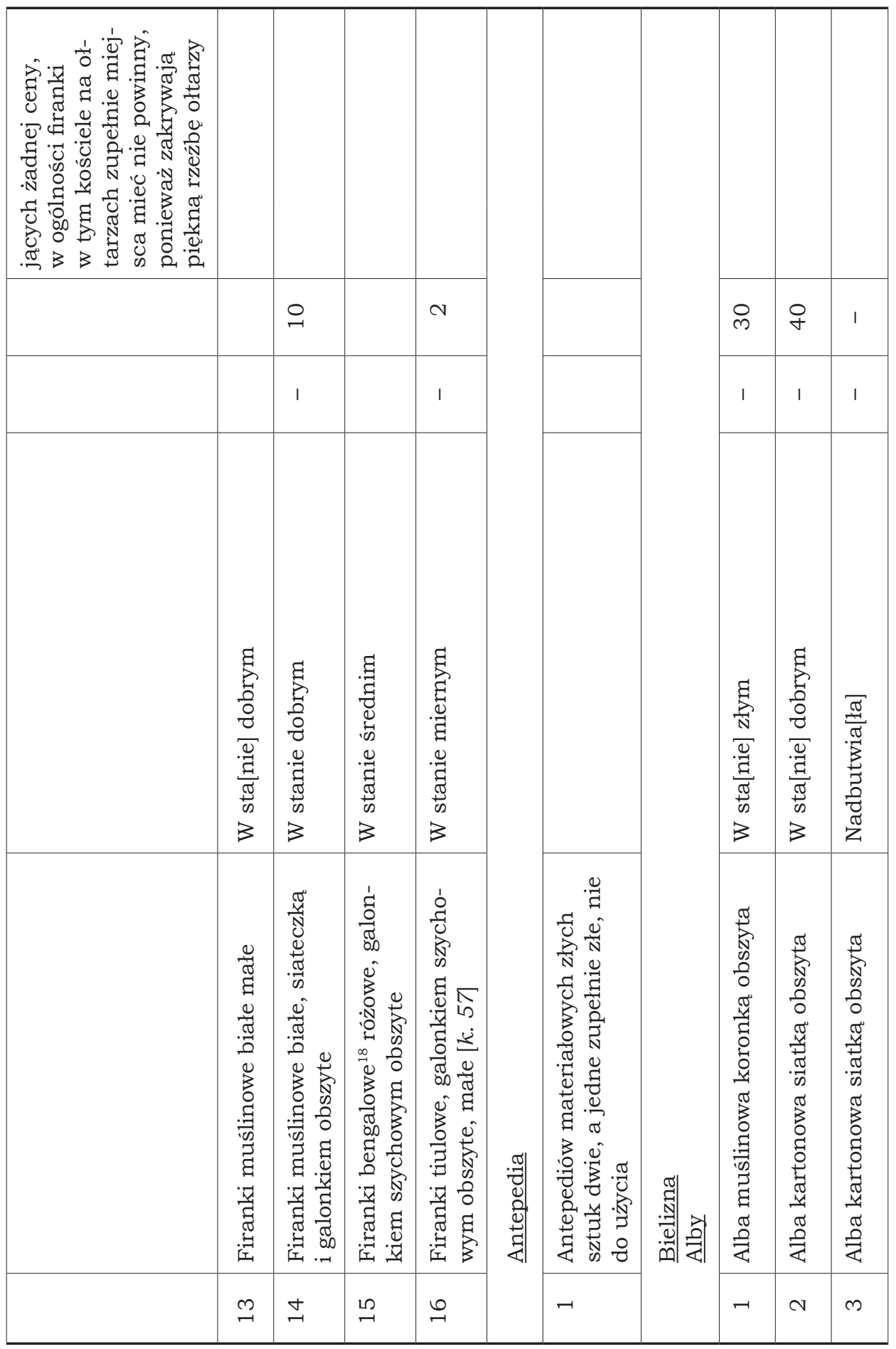




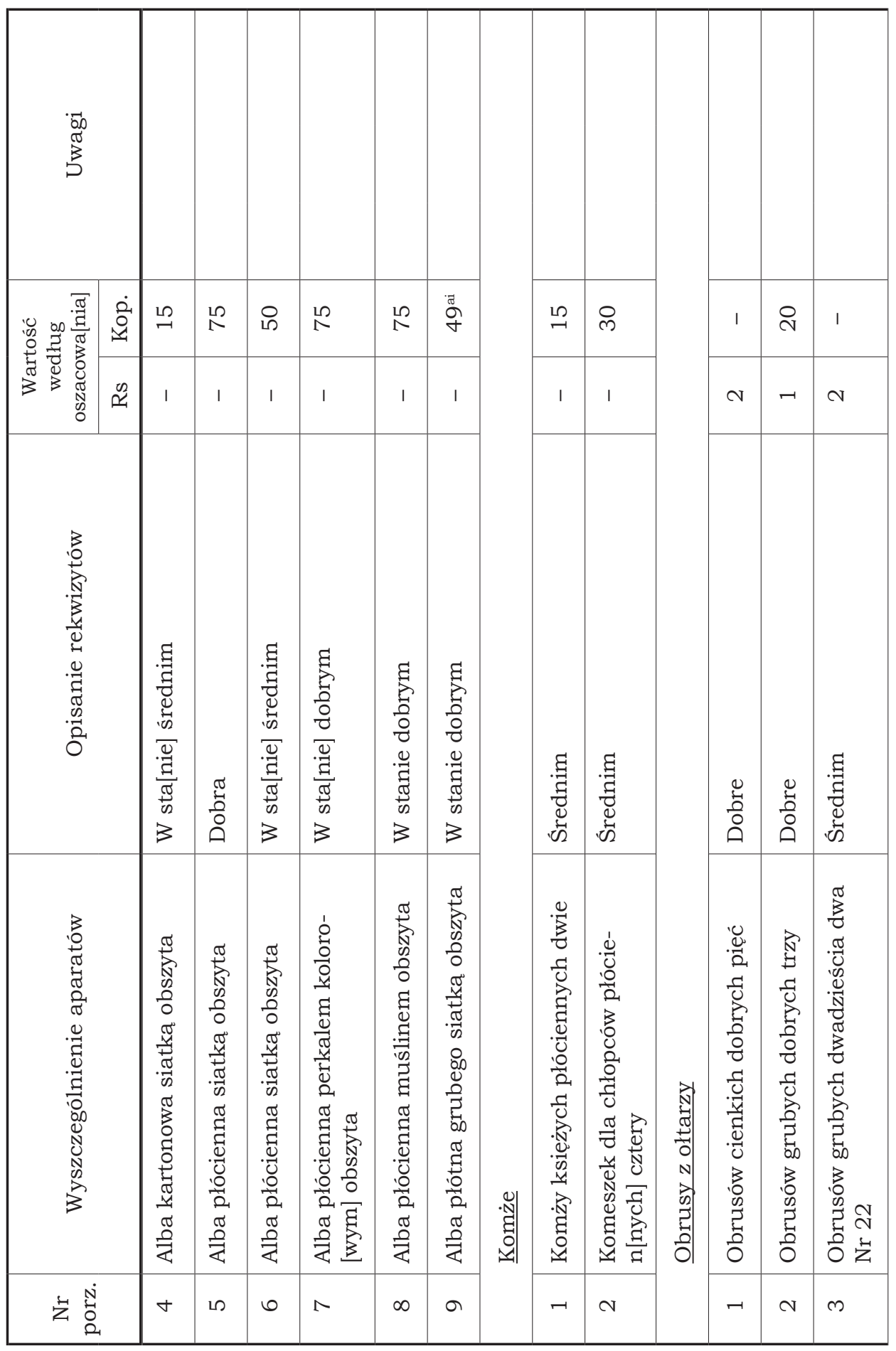


Wystrój i wyposażenie kościoła parafialnego...

351

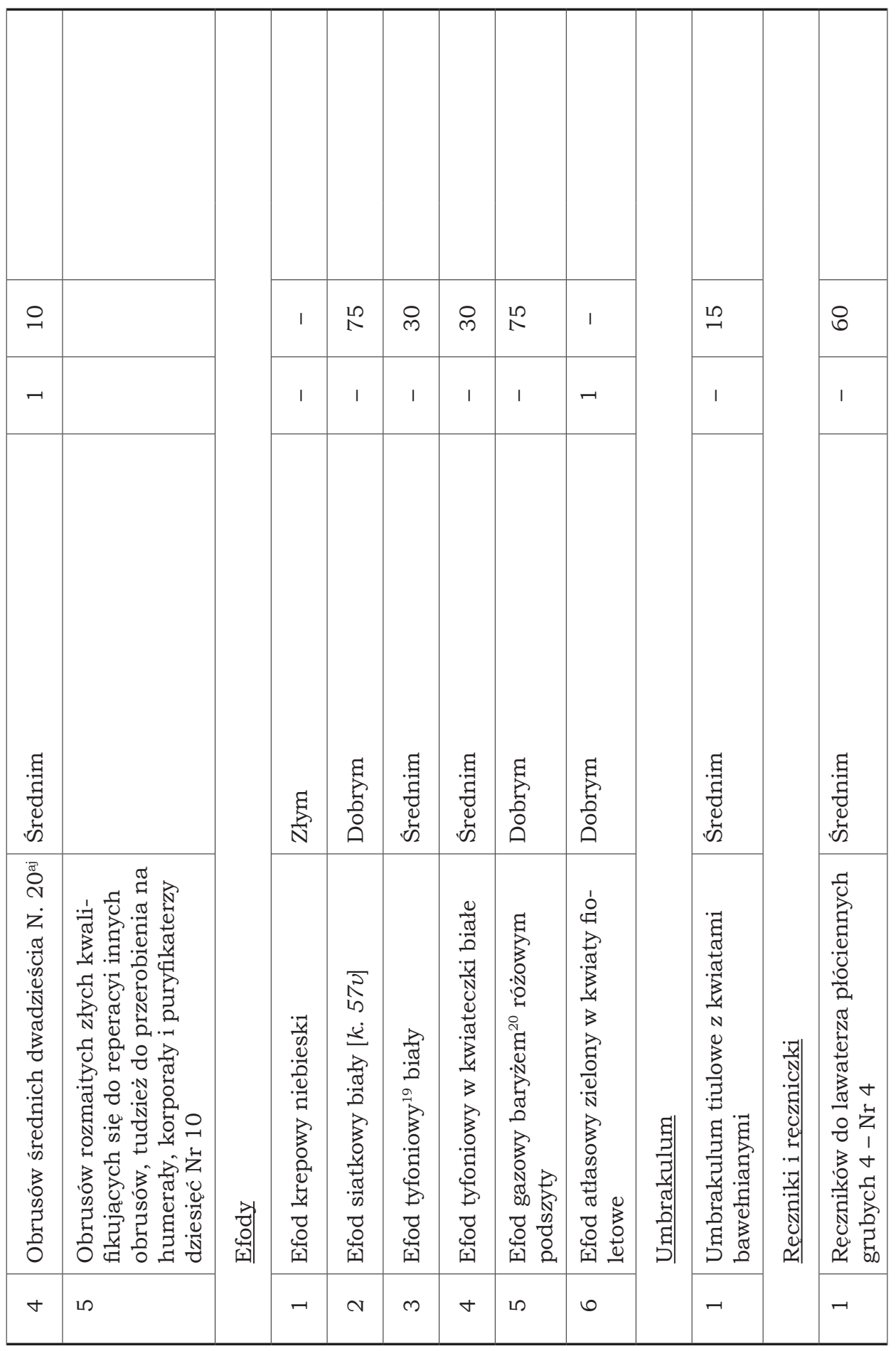




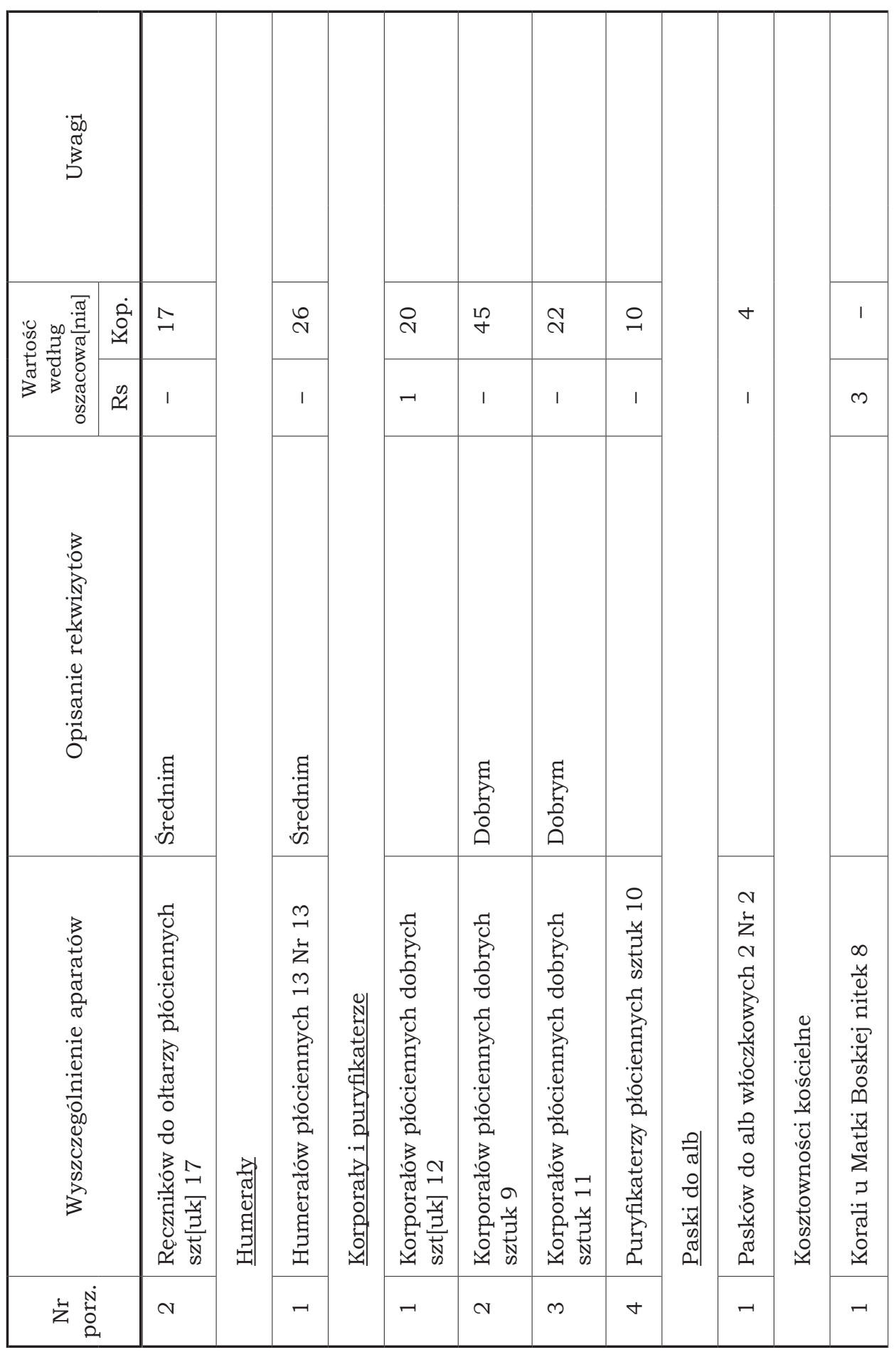


Wystrój i wyposażenie kościoła parafialnego... 353

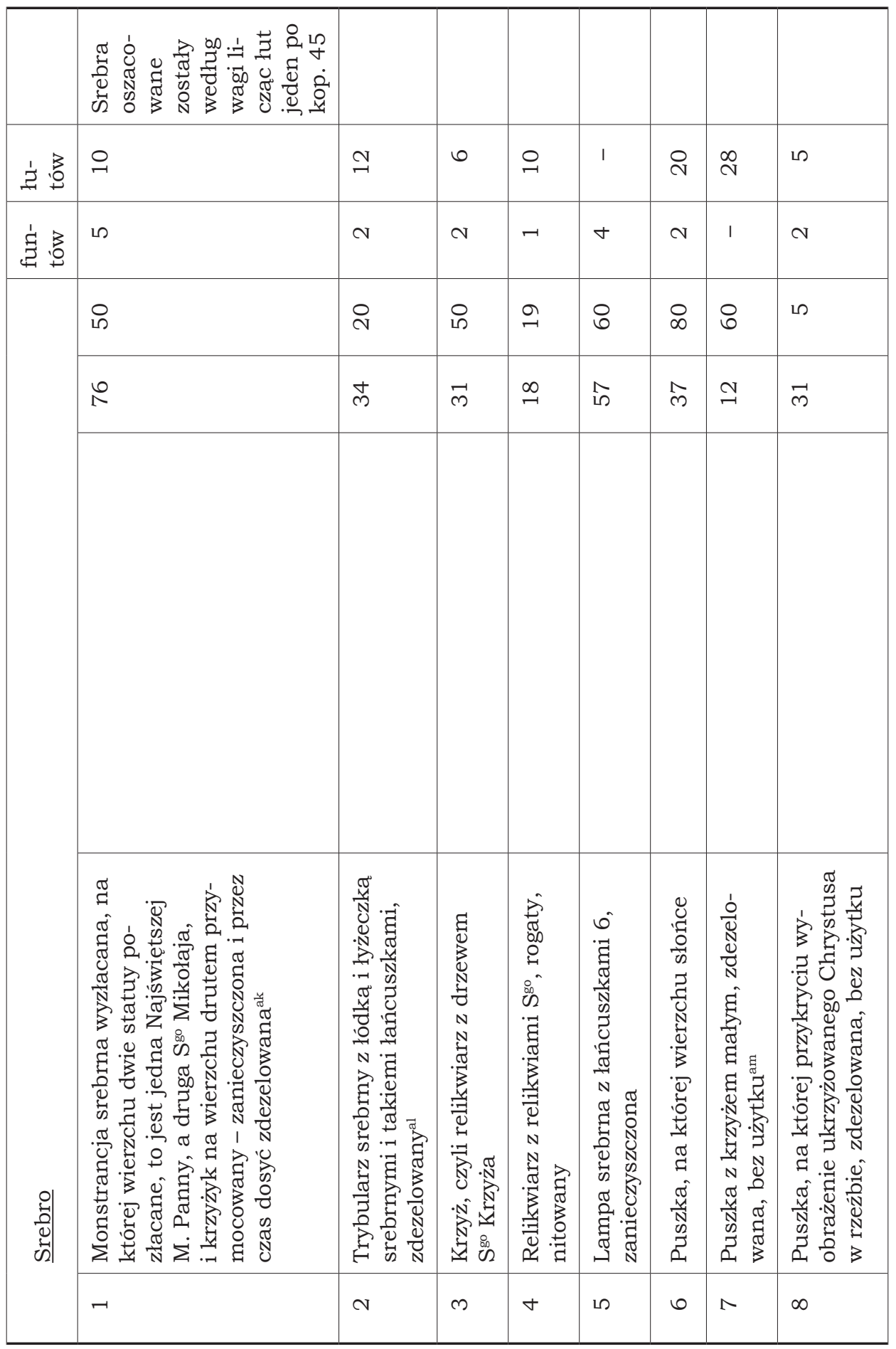




\begin{tabular}{|c|c|c|c|c|c|c|c|c|c|c|c|c|c|}
\hline \multicolumn{2}{|l|}{$\begin{array}{l}\overrightarrow{50} \\
\sqrt{\sigma} \\
3 \\
5\end{array}$} & $\stackrel{10}{\sim}$ & $\stackrel{\infty}{\infty}$ & $\underset{\sim}{ \pm}$ & $\stackrel{\infty}{\sim}$ & $\exists$ & N & L & $\infty$ & $\infty$ & $\infty$ & & ஓ \\
\hline & & -1 & $\neg$ & $N$ & 1 & -1 & N & N & 1 & 1 & 1 & & 1 \\
\hline iv & مُ & $\stackrel{n}{\sim}$ & $\stackrel{\vec{N}}{\stackrel{N}{N}}$ & ণ & 8 & $\stackrel{\text { ஜि }}{\oplus}$ & $\stackrel{P}{\wedge}$ & ம & రి & ○ & ○ & 1 & 으 \\
\hline $\begin{array}{lll}3 & 3 & 0 \\
0 \\
& & 0 \\
0 & 0 \\
0 & 0\end{array}$ & $\tilde{2}_{1}^{2}$ & $\overrightarrow{\mathrm{N}}$ & $\stackrel{\infty}{\sim}$ & ஸि & $\stackrel{\sim}{\sim}$ & $\stackrel{\curvearrowright}{\sim}$ & 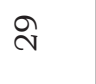 & $\vec{m}$ & $n$ & $n$ & $m$ & I & $\stackrel{M}{\sim}$ \\
\hline 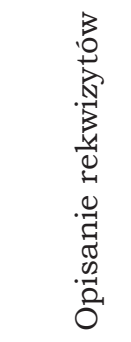 & & & & & & & & & & & & & \\
\hline 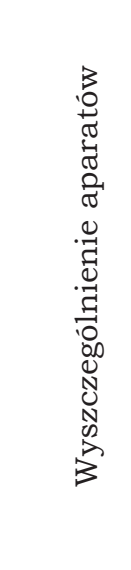 & & 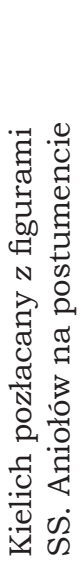 & 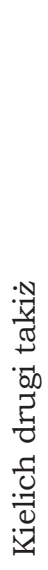 & 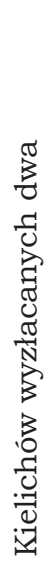 & 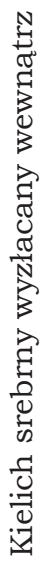 & 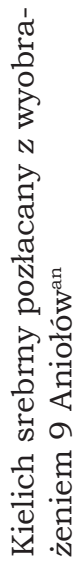 & 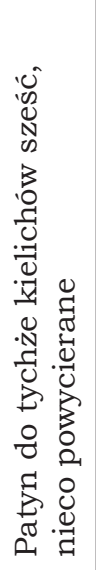 & 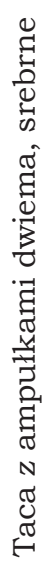 & 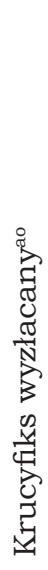 & 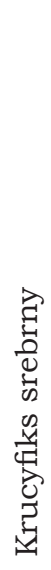 & 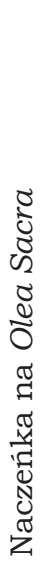 & 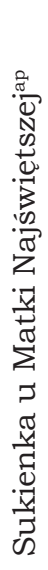 & 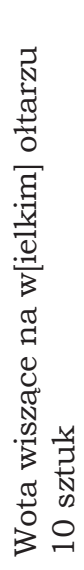 \\
\hline 之 & & $a$ & $\stackrel{ }{-}$ & $\beth$ & $\stackrel{\sim}{\sim}$ & $\stackrel{M}{\sim}$ & $\stackrel{\Xi}{\sim}$ & $\stackrel{10}{\sim}$ & $\stackrel{0}{\sim}$ & $\stackrel{-}{\sim}$ & $\stackrel{\infty}{-1}$ & $\stackrel{\sim}{\sim}$ & ণ \\
\hline
\end{tabular}


Wystrój i wyposażenie kościoła parafialnego... 355

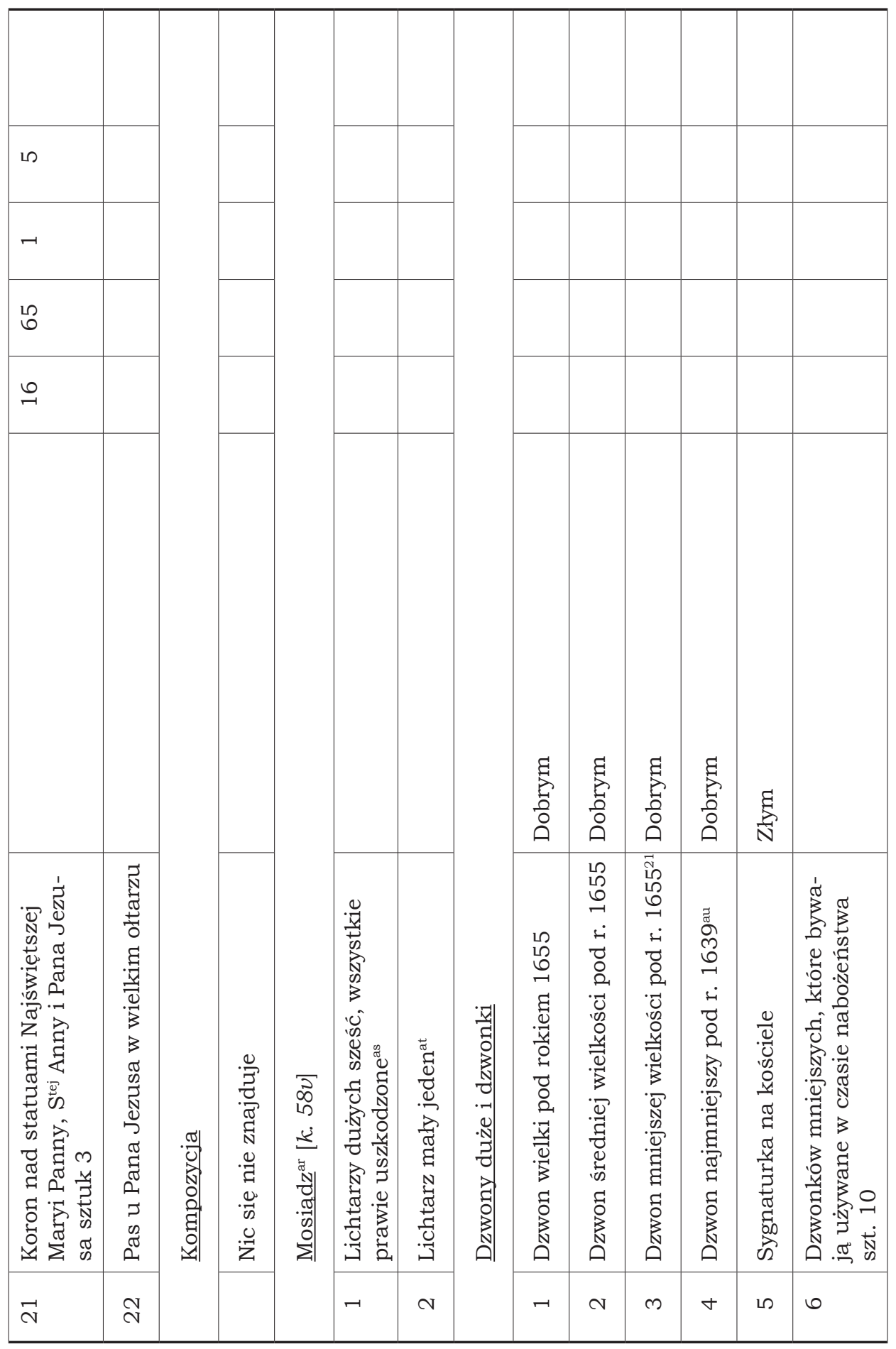




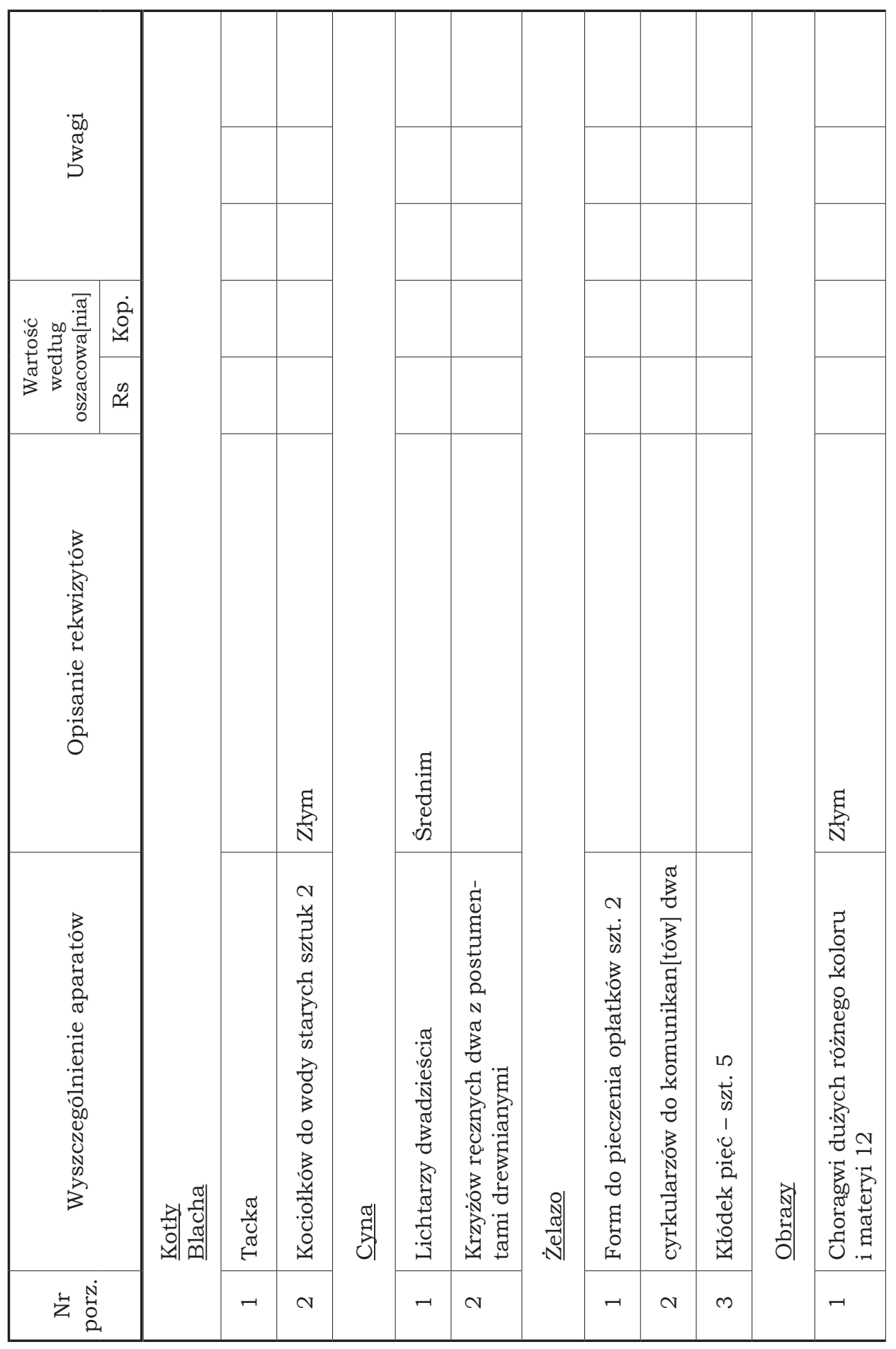


Wystrój i wyposażenie kościoła parafialnego... 357

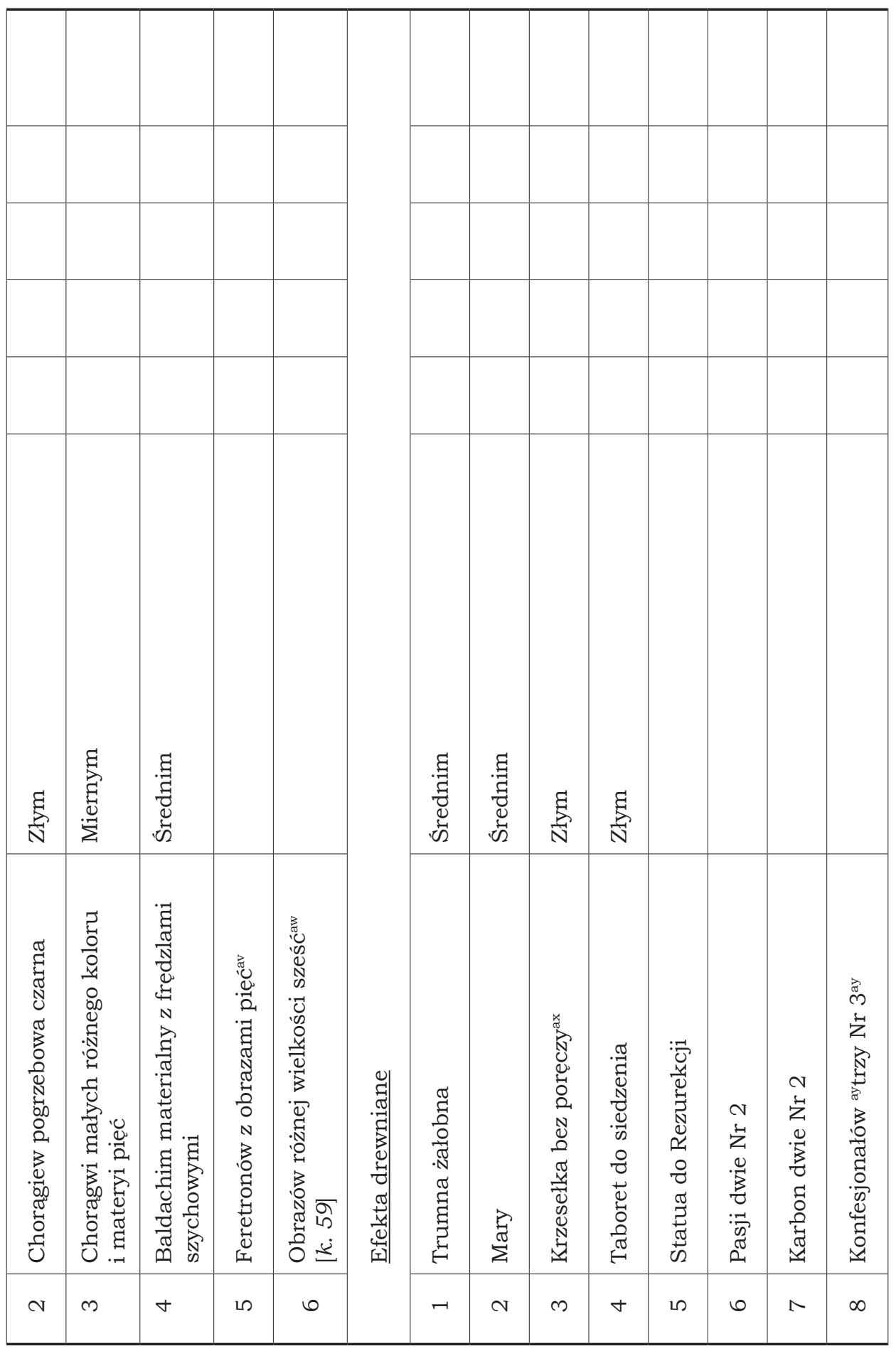




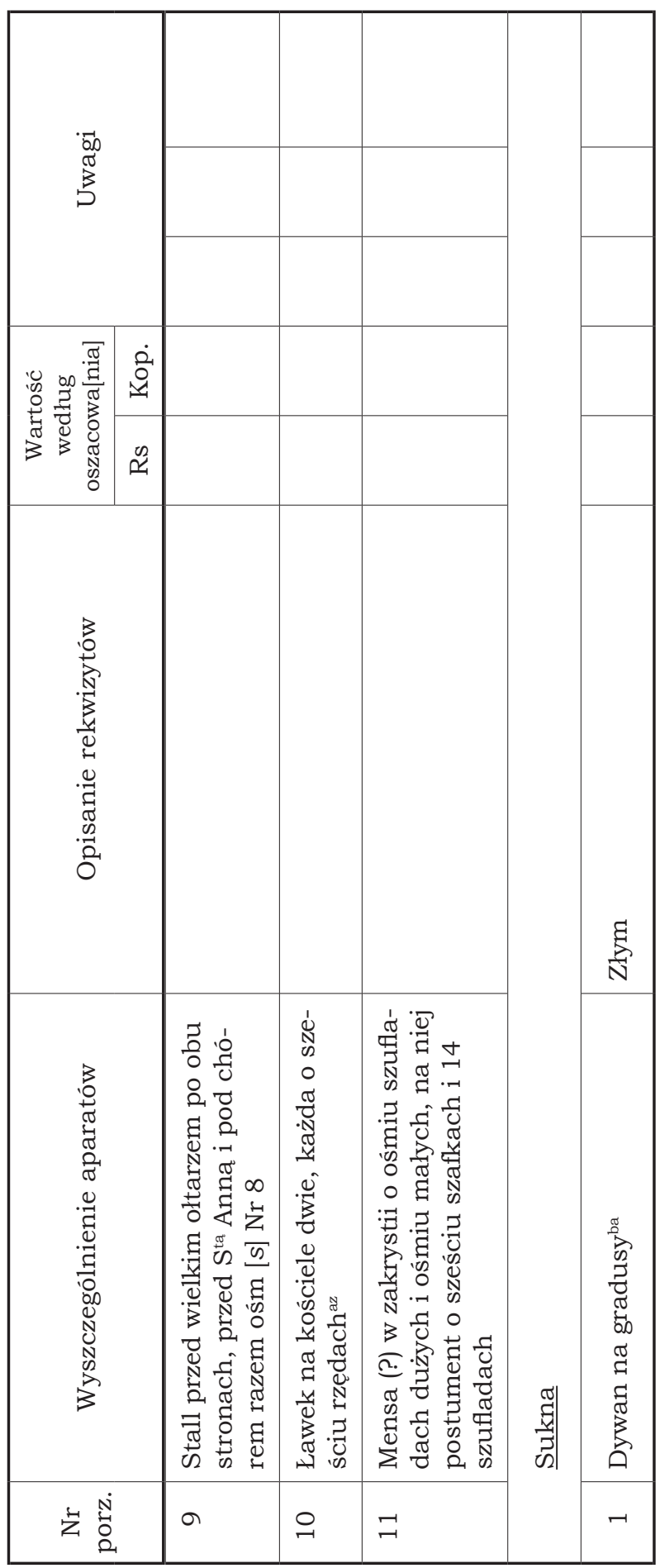

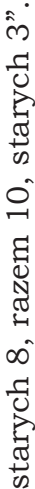

+ $\hat{\mathrm{N}}$

पू山

충유

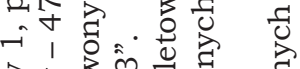

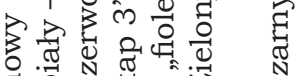

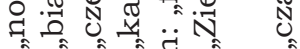

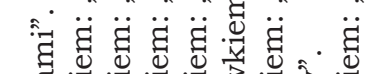

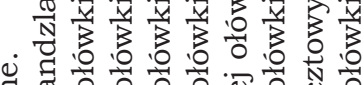
E $\pi 00000000$

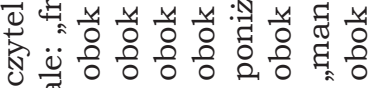

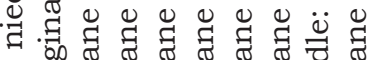

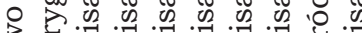

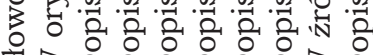
$\vec{v} 3 \circ \circ$ 


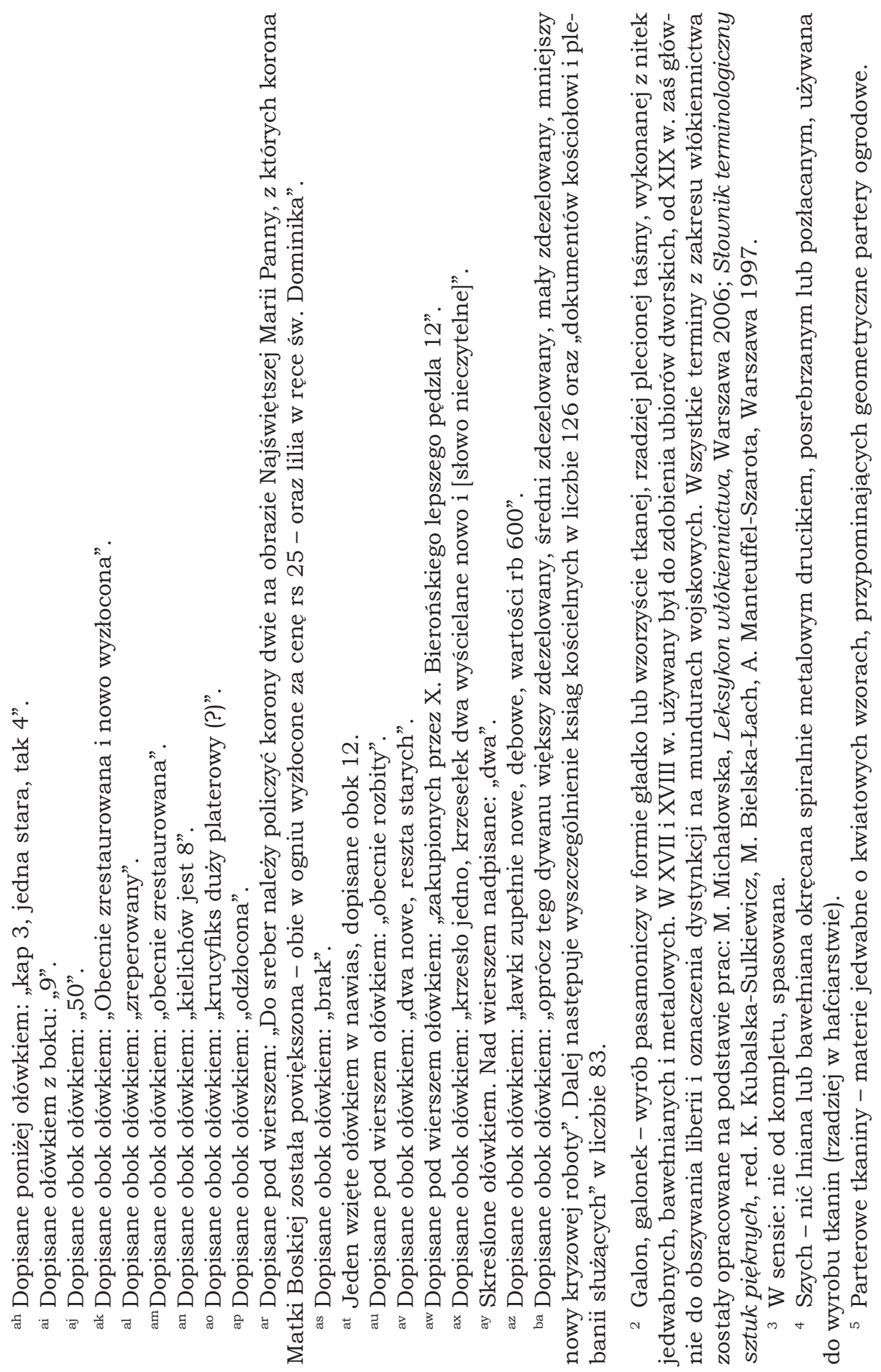




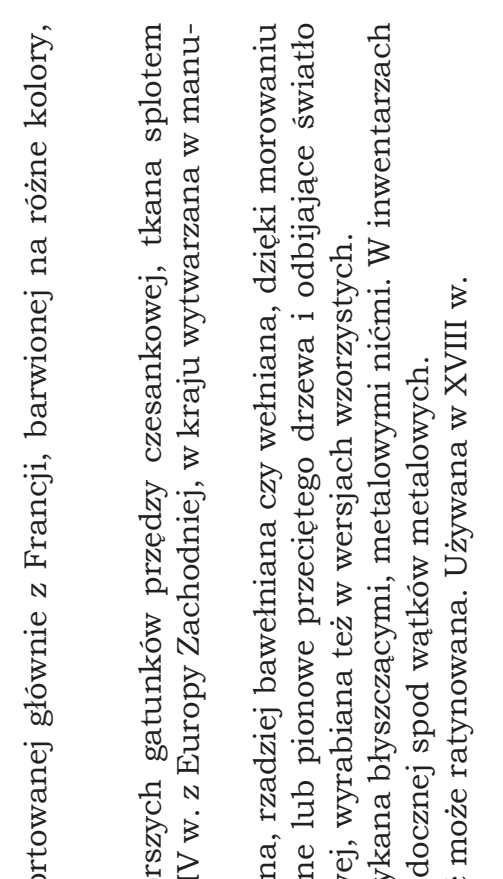

童

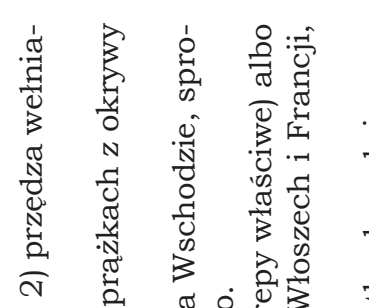

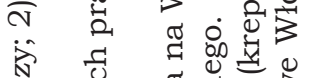

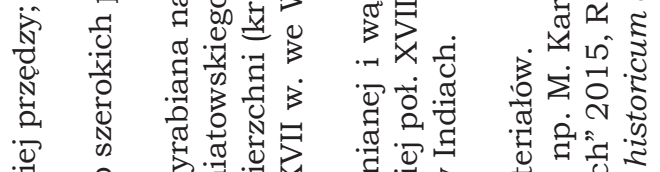

ब क

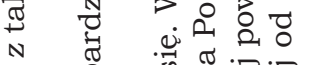

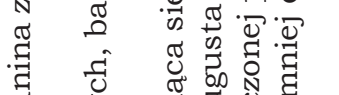

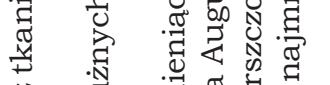

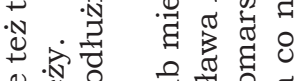

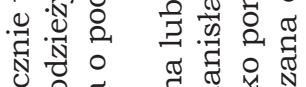

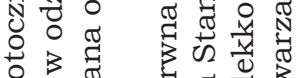

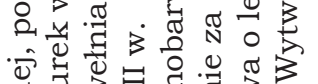

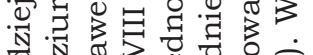

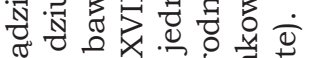

हే

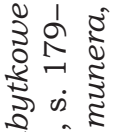

वै

के วี

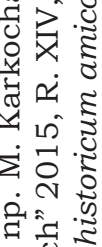

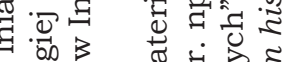

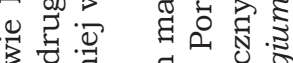

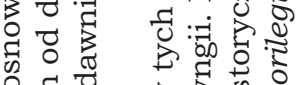

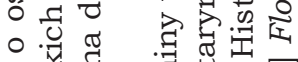

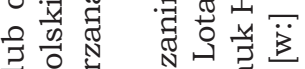

ह

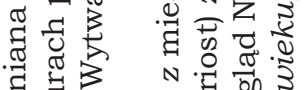

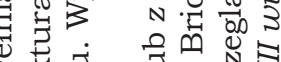

氙 욜

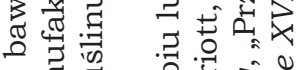

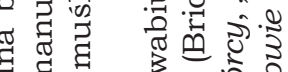

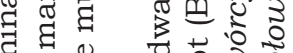
告.

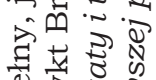

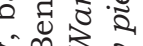
胥 $3 . \frac{2}{2} \frac{1}{2}$ ง $\frac{0}{0}$ ปั

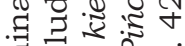

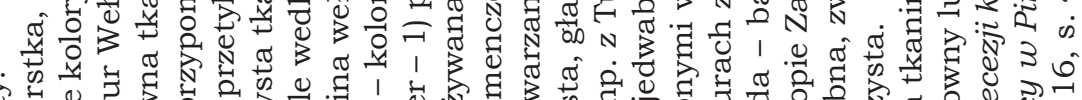

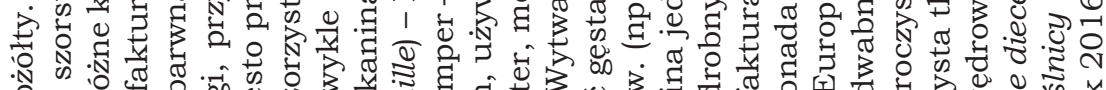

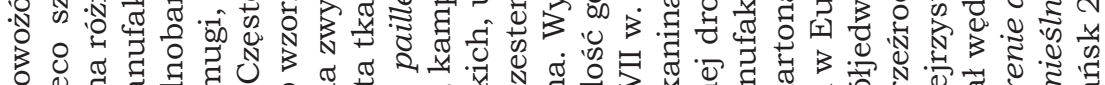

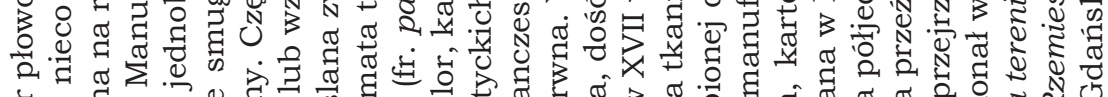

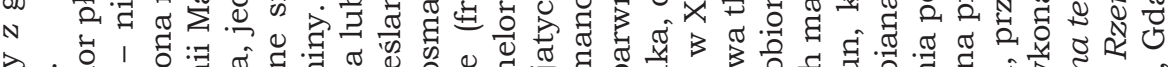

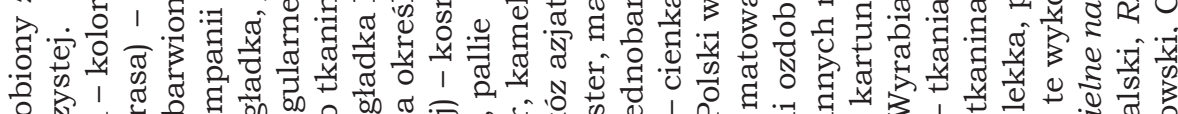

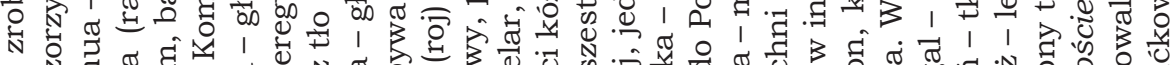

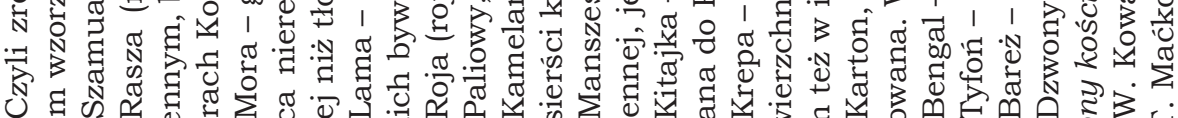

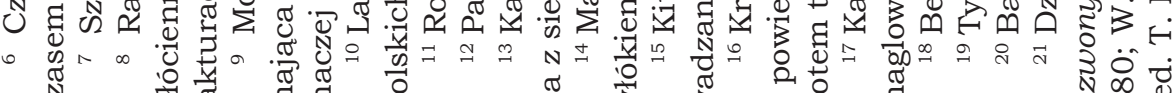

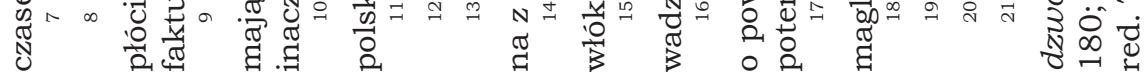




\section{Bibliografia}

\section{ŹRÓDEA ARCHIWALNE}

Archiwum Diecezjalne w Kielcach

Akta konsystorskie. Status cleri 1847-1929, sygn. OP-X/13.

Akta konsystorskie ogólne. Życiorysy kapłanów 1835, sygn. OP-X/4b.

Akta konsystorskie ogólne. Życiorysy kapłanów 1835-1840, sygn. OP-X/3.

Akta personalne ks. Nestora Bierońskiego 1842-1890, sygn. XB-19.

Małogoszcz. Dokumenty różne z XIX wieku (luzem, nieuporządkowane), sygn. IIPM-I/6.

\section{WYDAWNICTWA ŹRÓDEOWE}

Zbiór dokumentów małopolskich, wyd. S. Kuraś, I. Sułkowska-Kuraś, cz. 4 (Dokumenty z lat 1211-1400), Wrocław-Warszawa-Kraków 1969.

\section{Opracowania}

Achremczyk S., Marchwiński R., Przeracki J., Poczet biskupów warmińskich, Olsztyn 1994.

Giebartowski W., Ś.p. ks. Nestor Bieroński, „Przegląd Katolicki” 1899, R. XXXVII, nr 18, s. 281-284.

Hadamik C., Kalina D., Traczyński E., Miasto i gmina Małogoszcz, Kielce 2006 [seria: Dzieje i zabytki małych ojczyzn, red. R. Mirowski].

Instrukcja wydawnicza dla źródeł historycznych od XVI do połowy XIX wieku, red. K. Lepszy, Wrocław 1953.

Karkocha M., Opis wizyty dziekańskiej kościoła parafialnego w Małogoszczu z roku 1830, „Przegląd Nauk Historycznych” 2016, R. XV, nr 2, s. 261-283.

Karkocha M., Parafia Rembieszyce 1438-2012. Studium z dziejów społeczności lokalnej, Łódź 2013.

Karkocha M., Uposażenie parafii Małogoszcz $w$ świetle sumariusza $z 1792$ r., „Przegląd Nauk Historycznych” 2016, R. XV, nr 1, s. 249-276.

Karkocha M., Zabytkowe dzwony kościelne na terenie diecezji kieleckiej. Warsztaty i twórcy, „Przegląd Nauk Historycznych” 2015, R. XIV, nr 2, s. 179-180.

Katalog zabytków sztuki w Polsce, t. III (Województwo kieleckie), red. J.Z. Łoziński, B. Wolff, z. 3 (Powiat jędrzejowski), oprac. T. Przypkowski, Warszawa 1957.

Kosik E., Chrostowice z Małogoszcza, „Nasza Przeszłość” 1973, R. XL, s. 175-182.

Kosik E., Parafia małogoska, [w:] W kasztelańskim Małogoszczu. Monografia historyczno-gospodarcza Małogoszcza i okolicy, red. E. Kosik, Kielce 1994, s. 59-66.

Kosik E., Paulewicz M., Budowniczy Małogoszcza Jakub Bieda Chrostkowicz, [w:] W kasztelańskim Małogoszczu. Monografia historyczno-gospodarcza Małogoszcza i okolicy, red. E. Kosik, Kielce 1994, s. 67-70. 
Kowalski W., Rzemieślnicy $w$ Pińczowie $w$ pierwszej połowie XVII wieku, [w:] Florilegium historicum amicorum munera, red. T. Maćkowski, Gdańsk 2016, s. 423-424.

Kumor B., Dzieje diecezji krakowskiej do roku 1795, t. I, Kraków 1998.

Łętowski L., Katalog biskupów, prałatów i kanoników krakowskich, t. II (Biskupi krakowscy), Kraków 1852.

Michałowska M., Leksykon włókiennictwa, Warszawa 2006.

Nitecki P., Biskupi Kościoła w Polsce w latach 965-1999, Warszawa 2000.

Rawita-Witanowski M., Dawny powiat chęcinski, oprac. D. Kalina, Kielce 2001.

Słownik terminologiczny sztuk pięknych, red. K. Kubalska-Sulkiewicz, M. Bielska-Łach, A. Manteuffel-Szarota, Warszawa 1997.

Stuczeń S. ks., Parafia małogoska i jej ostatni proboszcz ś.p. ks. prałat ks. Nestor Bieroński, „Przegląd Katolicki” 1899, R. XXXVII, nr 19, s. 296-297; nr 21, s. 328-330; nr 22, s. 345-346.

Wiśniewski J., Historyczny opis kościołów, miast, zabytków i pamiatek $w$ Jędrzejowskiem, Marjówka 1930, reprint Kielce 2000.

Zapałowa K., Rodzina Stefana Żeromskiego w Świętokrzyskiem, Kielce 2003. 